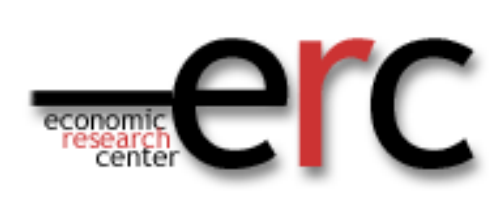

ERC Working Papers in Economics 14/06

June/ 2014

\title{
Health Behaviors and Education in Turkey
}

\author{
Aysit Tansel \\ Department of Economics, Middle East Technical University, Ankara, Turkey and \\ Institute for the Study of Labor (IZA) Bonn, Germany and \\ Economic Research Forum (ERF) Cairo, Egypt \\ E-mail: atansel@metu.edu.tr \\ Phone: + (90) 3122102073 \\ Deniz Karaoğlan \\ Department of Economics, Middle East Technical University, \\ Ankara, TURKEY \\ E-mail: kadeniz@metu.edu.tr \\ Phone: + (90) 3122103069
}




\title{
HEALTH BEHAVIORS AND EDUCATION IN TURKEY
}

\author{
Aysit Tansel \\ Department of Economics \\ Middle East Technical University, Ankara, Turkey and \\ Institute for the Study of Labor (IZA) Bonn, Germany and \\ Economic Research Forum (ERF) Cairo, Egypt \\ E-mail: atansel@metu.edu.tr \\ Telephone: 90.312 .2102073 \\ Fax : 90.312.210 7964 \\ and \\ Deniz Karaoglan \\ Department of Economics \\ Middle East Technical University, Ankara, Turkey \\ E-mail: kadeniz@metu.edu.tr \\ Telephone: 90.312 .2103069 \\ Fax: 90.312.210 7964
}

June 20, 2014

\begin{abstract}
This is the first study which provides empirical analysis of the variation in health behaviors for adult men and women in Turkey which is a developing country. The health behaviors considered are smoking, drinking, fruit and vegetable consumption, exercise and body mass index (BMI). We find that in Turkey education is the most important factor that affects the health behaviors. The results indicate that smoking is positively associated with education at all levels with a decreasing effect with the level of education unlike in the developed countries. This result indicates that smoking is a serious public health problem in Turkey at all levels of education. Further, alcohol consumption and schooling are positively related and it increases by the level of education. Higher educated individuals clearly eat more fruits, vegetables and exercise more and their BMI levels are in the normal range compared to less educated and illiterate. We also highlight the importance of demographic factors, labor market status and household income. We use Health Survey of Turkish Statistical Institute (TURKSTAT) for years 2008, 2010 and 2012. This study will provide a baseline for further studies on the various aspects of health behaviors in Turkey.
\end{abstract}

Keywords: Health Behaviors, Education, Demographic Factors, Turkey JEL Classicification: I10, I12, I19 


\section{Introduction}

Grossman (1972) is one of the earliest economists who provide formal explanations of the observed differences in health behaviors by education. Importance of this topic is due to the fact that differences in health outcomes are mainly related to differences in health behaviors although observed health behaviors do not explain all of the differences in health outcomes. Mokdad et al. (2004) estimate that almost half of the adult mortality in the US are ascribed to risky health behaviors. Cutler and Lleras-Muney (2008) and a number of studies focus on differences in lifeexpectancy by education in the US and the UK. Lleras-Muney (2005) examines the relationship between education and adult mortality in the US. Cutler and Lleras-Muney (2010) emphasize that health outcome differences by education need to be explained by health behavior differences by education. These differentials in health behaviors by education are studied mostly in developed countries. However, there is less evidence on this issue in developing countries. Thus, the purpose of this paper is to examine the health behaviors by education in Turkey which is a developing country. We will also highlight the differences in health behaviors by other indicators such as demographic factors, labor market status and household income.

Risky health behaviors negatively affect the individual's health. For instance, as the frequency of risky health behaviors increase, people are more likely to report poor self-assessed health (SAH) (Brunello et al., 2011), which is a good predictor of mortality (Idler and Benyamini, 1997). Risky health behaviors also lead to serious diseases such as cardiovascular diseases, cancer, diabetes, etc... Some of the articles related to this are Cawley and Ruhm (2011), Hung et al. (2004) and Stewart et al. (2009) among others. Hence, it is important to determine the variations in risky health behaviors.

The health behaviors considered in this study are smoking, alcohol consumption, fruit and vegetable consumption, exercise and body mass index (BMI). Among these health behaviors, smoking and BMI are the ones that are examined most often in the literature. Example of these studies include Cutler et al. (2003), Cutler and Gleaser (2005), De Walque (2007), Chaloupka and Warner (2000), Mullahy (1997), Gruber and Frakes (2006) and Carbone et al. (2005). There are several studies which investigate the relationship between risky health behaviors and various educational and demographic factors that might influence them. Cutler and Lleras-Muney (2010) study this relationship in the USA and the UK. An earlier study, Kenkel (1991) and Lantz et al 
(1998 and 2001) also investigate this relationship in the USA. Ettner (1996) examines the effect of socioeconomic status of the individual and alcohol consumption in the USA. There are other studies that examine the relationship between risky health behaviors and education for developed countries other than the USA. For instance, Kemptner et al. (2011) examine this relationship for West-Germany. They look at the association between education and smoking as well as obesity. Brunello et al. (2013) examine the relationship between schooling and obesity for the case of 13 European countries. Webbink et al. (2010) examine the education and obesity relationship in Australia (2010). It is important to note that these studies do not always indicate the expected negative association between risky health behavior and education. For instance, Kenkel (1991) finds in USA that although education positively and significantly affects the frequency of exercise and negatively and significantly affects smoking, its effect on alcohol drinking is positive. Similarly, another study, Kemptner et al. (2011) find that although an increase education level decreases the likelihood of being obese for both men and women in West-Germany, there is no significant link between education and smoking.

This is the first study that investigates the relationship between health behaviors and education in Turkey. Previous literature on the determinants of health behaviors in Turkey is very limited and mostly focus on one health behavior at a time. For instance, Tansel (1993) examines the tobacco consumption in Turkey. She finds a larger decrease in demand for tobaccos if people are educated about the harmful effects of smoking than if there is an increase in tobacco prices. In another study, Erem et al. (2004) investigate the determinants of obesity in Trabzon, a city located in the Black Sea Region of Turkey. Two of their main findings are that obesity increases with age and it is more prevalent among women than among men. They also discuss the factors which affect BMI levels. Hatemi et al. (2003) study the relationship between hypertension and obesity for 11 different cities located in four different regions of Turkey. Other studies related to the determinants of health behaviors in Turkey include Metintaş et al. (1998), Erbaydar et al. (2005), Kocabaş et al. (1994) and Yumuk (2005).

In this paper, we examine the determinants of health behaviors for adult population in Turkey using Turkish Health Survey data set for the years 2008, 2010 and 2012. Probit models (OLS for BMI) are used to estimate determinants of health behaviors. We find that education has the 
strongest effect on all of the health behaviors considered. University graduates tend to smoke less, consume more fruits and vegetables, and exercise more frequently than less educated individuals. In addition, they have lower BMI levels compared to the less educated ones. Alcohol consumption is an exception to these evidences. Our results indicate that highly educated people tend to consume more alcohol than less educated people.

This paper is organized as follows. Section 2 presents the theoretical framework. Section 3 provides a description of the Turkish Health Survey data used in this study. Section 4 describes the empirical specification used in estimation. Section 5 presents the empirical results using Turkish Health Survey data. Finally, concluding remarks are provided in Section 6.

\section{Theoretical Framework}

The first theoretical model for demand for health is developed by Grossman (1972). Grossman emphasizes that health is a durable capital stock that deteriorates with time. He argues that health capital is different from education in the sense that while education determines the individual's time productivity (such as wages), the stock of health determines the total amount of productive time an individual uses freely. The relationship between the two forms of human capital is examined in Grossman's (1972) model. In his model health is determined within the model (endogeneous) whereas education is taken as exogeneous. He concludes that education is positively associated with health capital and negatively associated with expenditures on health care.

Demand for health also varies with the rate of depreciation on the stock of health which is assumed exogenous Grossman argues that depreciation rate rises with age and falls with higher levels of education. As a result demand for good health decreases and expenditure on medical care increases. The associations of wage rate with the demand for good health and health care are positive Higher levels of education enhance the wage rate and wage rate improves the quality of individual's health capital.

Bolin (2011) extends Grossman's (1972) model to continuous time. He solves the individual's utility maximization problem and derives predictions on how education, age and wage rate affect the individual's health level. He argues that education influences the demand for health in two ways. First, education enhances household production efficiency (the efficiency effect), second, 
education increases the cost of own time used in household production since it rises the market productivity and hence the wage rate (the time-price effect). Efficiency effect decreases the marginal cost of producing health capital since fewer resources are used to produce a certain quantity of gross health investments. Therefore, efficiency effect increases the demand for health. On the other hand, the time price effect causes a decrease in health demand because marginal cost of health capital increases due to a higher unit cost of own time. However, the time price effect cannot outweigh the efficiency effect, or the two effects cannot completely offset each other, since individual's own time is not the only input to health production. In other words, the positive effect of education always dominates its negative effect. In Bolin's model a higher wage rate increases the value of available healthy time, therefore as wage increases, the incentives for being healthy strengthen. On the other hand, higher wage rate makes own time used for producing gross investments in health more expensive. A higher cost of own time will increase the marginal cost of health capital leading to a decrease in the demand for health. As in the education case, positive effect of wage rate on health always dominates the negative effect of wage rate on health since individual's own time is not the only input that produces health. In Bolin's model as age increases, the possibility of having a certain level of health decreases. As the rate of depreciation increases over time, the model also predicts that health decreases with age. Because the rate of depreciation increases with age, the equilibrium amount of health (therefore the demand) for the old individual is lower than the health for the young individual.

The covariates, which explain the variations in health outcomes, discussed in previous paragraphs are not health related behaviors. In the theory, health related behaviors are also used as input for health production. In Grossman's both 1972 and 2000 health demand models medical care is the only health input. However, as Grossman (2000) suggests, it is oversimplification because other market goods and services such as housing, diet, recreation, tobacco consumption and excessive alcohol use also influence health. Grossman states that smoking and excessive alcohol consumption have negative marginal products in the production of health. However, they are purchased since these risky behaviors may have positive marginal products in producing some commodities such as "smoking pleasure". 


\section{Data}

This study uses the results of Turkish Health Survey (THS) for Turkey for the years 2008, 2010 and 2012. THS is cross sectional data set over individuals. It is prepared and conducted by Turkish Statistical Institute (TURKSTAT). In this survey health related questions are asked separately for 3 different age groups, 0-6, 7-14 and 15 or above. In this paper, we concentrate on the individuals who are 25 or above in order to analyze the determinants of health behaviors of adult men and women, who are assumed to complete their schooling. Since we do not observe significant differences between their main results when we use the surveys separately, we pool the THSs of 2008, 2010 and 2012 in our analysis of the determinants of health behaviors in Turkey ${ }^{1}$.

Next, in THS, we are able to observe the demographic factors of the respondents above 25 , such as age, gender, education level, marital status, household income, region (urban/rural) and labor market status (employed, unemployed or out of labor force). In THS age is given in six categories: "25-34, 35-44, 45-54, 55-64, 65-74 and 75+"2. We used mid-points of these age categories in our analysis. Marital statuses of the respondents are grouped into three as married, single and widowed/divorced. The respondent is referred as widowed if his/her wife/husband is dead or he/she is divorced if he/she is separated from his/her wife/husband legally. Since widowed and divorced individuals have similar history (are married before but now live alone) we combine them into one in our analysis. We define the years of schooling in the following manner: If the individual is illiterate, his/her years of schooling is equal to 0 . If the individual knows reading/writing, but he/she is not a graduate from any school then his/her years of schooling is equal to 2 . The individual's years of schooling is equal to 5,8 and 11 if he/she has completed primary, middle and high school respectively. Finally, the individual's years of schooling is equal to 15 if the individual has university or higher degree. In addition, we also classify education into six groups: Illiterate, literate but is not graduate of any school (nongraduate), and graduates of primary school, middle school, high school and university or higher degree. We test the effect of each education category on individual's health behavior. Lastly, we considered three employment statuses of the individuals as employed, unemployed and inactive.

\footnotetext{
${ }^{1}$ Separate analysis of the 2008,2010 and 2012 surveys are available from authors upon request.

${ }^{2} 0-6,7-14,15-24$ age groups are also in the data set. We exclude them from the sample as we concentrate on adults, who complete their schooling, in this study.
} 
The respondents who have a regular job are referred to as "employed", whereas the individuals who are not working but are seeking job are considered as "unemployed". The respondents who are seasonal workers, students, housewives, pensioners, and the individuals who are unable to work are considered as inactive.

In this study, the health behaviors considered are smoking, alcohol consumption, fruit and vegetable consumption, exercise and the body mass index (BMI). With regards to smoking the following question was asked:

“Were you a regular tobacco consumer and do you still consume tobacco?”

If the response is, "Yes, everyday" or "Yes, sometimes", then the individual is considered as a tobacco consumer. In the empirical model for smoking behavior the dependent variable is equal to 1 if the individual has been a regular tobacco consumer and is currently a regular smoker and 0 if he/she does not smoke. Similarly, with regards to alcohol consumption the following question was asked:

"Did you consume alcohol regularly or occasionally and do you still consume alcohol?"

If the response is "Yes, everyday" or "Yes, sometimes", then the individual is considered as an alcohol consumer. In our empirical model for alcohol consumption behavior the dependent variable is equal to 1 if the individual consumes alcohol regularly or occasionally and 0 if he/she does not consume alcohol.

In addition, the individual is considered to be regular fruit and vegetable consumer if he/she states that he/she consumes fruits, vegetables and/or their juice at least once a week. In our analysis for fruit and vegetable consumption behavior health behavior outcome is equal to 1 if the individual consumes fruits, vegetables and/or their juice at least once a week and 0 otherwise. In THS we also observe the respondent's frequency of exercise. In THS, body exercises are divided into 3 categories: High level exercise (such as aerobic exercise or working in construction sector), medium level exercise (such as riding a bicycle or house work) and low level exercise (such as walking). The number of days in a reference week in which the respondent exercises using one of the above ways for at least 10 minutes gives the frequency of exercise in a week. In the empirical analysis for exercise behavior health behavior outcome is equal to 1 if the 
individual exercises at a high level or medium level or low level (walking), for at least 10 minutes in a week and 0 if he/she does not exercise in a given week. Lastly, in THS data set the respondent's self-reported height (in centimeters) and weight (in kilograms) are available. In order to calculate the BMI of an individual, we first convert the height into meters by dividing the reported height by 100, and then divide the reported weight of respondent (in kilograms) to the square of the height in meters. The resulting number gives the BMI of the individual which is used in our analysis.

\section{Emprical Specification}

The empirical specification of the model we estimate in this paper is as follows: Our health outputs are health related behaviors. They are smoking, alcohol consumption, fruit and vegetable consumption, exercise and individual's BMI level. We investigate the effect of input on each health related behaviors separately in five different models. Formally, we can write our health function as follows:

$$
\mathrm{H}=\mathrm{f}(\mathrm{E}, \mathrm{A}, \mathrm{G}, \mathrm{P}, \mathrm{M}, \mathrm{L}, \mathrm{HI})
$$

where $\mathrm{H}$ refers to health behavior. $\mathrm{H}$ is a function of education $(\mathrm{E})$, age $(\mathrm{A})$, gender $(\mathrm{G})$ the place where the individual lives (P), marital status (M), labor market status (L) and the household Income (HI). Education is exogeneous in our model. Grossman (2004) states that formal school completed is the most important determinant of good health whether the measure of the good health is mortality morbidity self-evaluation of health or psychological indicators of good health. In order to examine the effect of education on health behaviors accurately, we restrict our sample to individuals who are above 25 in our analysis, since approximately around age 25 , individuals complete their schooling in Turkey. As the theory supports that education is positively associated with good health, we assume that health behaviors that improve the quality of individual's health (Fruit and Vegetable Consumption, Exercise, Normal Ranges of BMI) are increasing in

education, whereas health behaviors that weakens the individual's health quality (Smoking, Alcohol Consumption, High Ranges of BMI) are decreasing in education. We add age in our model as the theory suggests that health is a capital that depreciates over time. Both Grossman (1972) and Bolin (2011) indicate that rate of depreciation decreases with education level and 
increases with age. Therefore, other things being equal we assume that $\mathrm{H}$ is increasing in $\mathrm{A}$ if the health behavior is risky when other factors remain constant. We do not observe individual's wage rate in THS data set. Therefore, we include household income as a proxy for the individual income. We also include individual's employment status in our model as a proxy for the socioeconomic status (SES) of the individual. As the theory suggests that higher income levels lead to better health status, we assume $\mathrm{H}$ is decreasing in $\mathrm{HI}$ if the health behavior is risky when other factors remain constant. We assume that the SES of the employed individuals is higher since employed individuals earn their own income and have more social networks than unemployed or inactive individuals. Cutler et al. (2011) state that low SES in occupation leads to psychosocial stress because of subordination feelings and lack of control. They indicate that this stress causes deterioration in health. Hence, we assume that the occurrence of risky health behaviors decreases with higher employment status. If we assume $\mathrm{E}$ is a number that increments if the individual finds a job or finds a better job if he/she is already employed then $\mathrm{H}$ is decreasing in E. Finally, we add the gender, the place where the individual lives, and marital status as covariates that explain the variation in health related behavior. These covariates are widely empirically examined. The literature suggest that females have better health status than males (Case and Paxson (2005), Fuchs (2004)). Hence, if we define "G" as 1 if the individual is male, and " 0 " if the individual is female, then we assume that $H$ is increasing in $G$ if $H$ corresponds to risky health behavior. In addition, empirical studies conclude that people living in more-favored places have better health statuses than people living in less-favored places (Reijneveld (2002)). In THS data set we observe whether the individual lives in urban or rural areas. We assume that living in urban areas are more preferred by individuals. Hence, if we define "P" as 1 if the individual lives in urban area, and " 0 " if the individual lives in rural area, then we assume that $\mathrm{H}$ is decreasing in $\mathrm{P}$ if $\mathrm{H}$ corresponds to risky health behavior. For marriage, the literature suggests that in general, married individuals are healthier than those who are not married since having a spouse is assumed to make positive contribution to an individual' health (Fuchs 2004). Therefore, we assume health behavior is a function of marital status (M). Defining $\mathrm{M}$ is equal to one if the individual is married then $\mathrm{H}$ is decreasing in $\mathrm{M}$ if $\mathrm{H}$ corresponds to risky health behavior. Finally we include dummy variables for the years 2010 and 2012 in our pooled sample (only 2012 for smoking). The determinants of variation in health behaviors are analyzed using a probit model (OLS for BMI). 


\section{Empirical Results}

In this section we present the effects of individual characteristics on each of the health behavior separately. For the probit analysis, we present the marginal effects (in percentages). We run five different probit regressions (OLS for BMI) in the following manner: In the first regression, explanatory variables included are; years of schooling, square of years of schooling and gender dummy. In the second regression, we add age, square of age and a dummy that indicates whether the individual lives in urban or rural areas. Next, in the third regression we add marital status dummies. In the fourth regression we add dummies which shows labor market status of the individual. Lastly, in the fifth regression we include the individual's household income (in logarithms). Here, our objective is to see whether the magnitude and significance of years of schooling variable changes when other controls are added into the regression. We observe that the magnitude of the years of schooling variable reduces slightly as new control variables are included in the regression but its significance never changes, which is consistent with the findings of Cutler and Llearas-Muney (2010).

Next, we replicate the five regressions for each health behavior by adding five dummy variables which indicate the education levels of the individuals in place of years of education. This is a flexible specification as suggested by the previous specification with years of scooling and its square. By doing this, first, we aim to see if there would be a change in the interpretation of our findings. We observe that the neither the explanatory power nor the sign of other control variables do not change. Second, we aim to see how the health behaviors vary among different education groups. Indeed, unlike the previous studies, THS data set enable us to see the variation of health behaviors among different education levels.

Year dummies for 2010 and 2012 are included in all of the regressions. For alcohol consumption, the coefficient of the 2010 year dummy is estimated as a positive indicating that compared to 2008 there has been an increase in alcohol consumption in 2010. On the other hand, the coefficient estimate of the 2012 year dummy is negative which implies that in 2012 compared to 2008 alcohol consumption decreased in Turkey. We also find that fruit and vegetable consumption decreased in 2010 and 2012 compared to 2008. The coefficient estimate of the year dummy for 2010 and 2012 are positive for exercise and individual's BMI level, 
which indicate that in 2010 and 2012 compared to 2008 there has been an increase in the prevalence of exercise and BMI levels. For smoking, only year dummy for 2012 is included in the regressions because smoking data are not available for 2008. We find that the coefficient estimate of the 2012 year dummy is negative. This suggests that in 2012 compared to 2010, there has been a raise in smoking in Turkey. In the rest of this paper we examine the each health behavior separately.

\subsection{Smoking}

OECD (2010) Health Data set reports that 25.4 per cent of adult population in Turkey is regular smoker which is the second highest after Estonia (26.2 per cent) among the OECD countries. Smoking is one of the most harmful health behaviors. Regular smokers are in great risk for cardiovascular disease, chronic lung disease and several types of cancer (Stewart et al., 2009; Chalupka and Warner, 2000). In THS data set smoking does not imply tobacco consumption only. It also includes other types of tobacco products such as cigars. We define an individual as smoker if he/she reports that he/she has been a regular smoker and he/she currently smokes. Table 1a presents the descriptive statistics for smoking for the pooled 2010 and 2012 survey $^{3}$. We observe that years of schooling is higher among smokers than nonsmokers. Nevertheless, the prevalence of smoking is the highest among middle school graduates. We also note that among males the percentage of smokers is larger than nonsmokers. The fraction of smokers is higher in urban areas than in rural areas. When we compare the married, single and widowed/divorced we see that the proportion of the smokers is highest among the singles. Regarding employment status, we see that percentage of smokers among unemployed is higher than those among the employed and inactive individuals. Finally, we see that household income is slightly higher among smokers.

Table $1 b$ reports the marginal effects (in percentages) from probit estimation results. We observe probability of smoking increases by 0.0384 percentage points when schooling increases by a year. The positive association between years of schooling and smoking in our study contradicts with previous studies such as Cutler and Learas-Muney (2010), Kenkel (1991) and Lantz et al. (2001). They all find a negative and significant relationship between years of schooling and smoking in the USA and UK which are developed countries. Turkey is considered as a

\footnotetext{
${ }^{3}$ Smoking data is available only for 2010 and 2012.
} 
developing country. For this reason, the relationship between education and smoking may differ in Turkey from that in the developed countries. Indeed the coefficient estimate of the years of schooling squared indicate that smoking and years of schooling has an inverted U-shaped relationship. This implies that the probability of smoking decreases among the highly educated. Table 1c reports the marginal effects (in percentages) (see also Figure 1) of probit estimation results where education dummies are used as education control variables instead of years of schooling. These results support our previous findings. We again find a positive relationship between smoking and education level which declines over education levels. For instance, the probability of smoking is lower for the individual with college or higher degree than that of the middle school graduate. The probability of smoking increases by 0.1727 percent for middle school graduates and by 0.0542 percent for college graduates relative to an illiterate individual. Hence, we conclude that individuals who have college degree are better informed about adverse health effects of smoking than the lower educated people.

The results for the other covariates are similar in Tables $1 \mathrm{~b}$ and $1 \mathrm{c}$. We comment on them briefly. We find that men are more likely to smoke than women. Smoking and age have concave relationship. Moreover, as it is expected, urban residents tend to smoke more than rural residents. Next, we see that married and single individuals are less likely to smoke than widowed / divorced. Further, we note that the probability of an unemployed smoking (0.1099) is twice as large as the probability of an employed smoking (0.0536) relative to inactive. This result can be attributed to the stressful work life for employed individuals, and to being anxious while looking for a job for the unemployed. Finally, we find that household income does not significantly affect individual's smoking behavior. Cutler and Llearas-Muney (2010) also include labor market status along with other main covariates. They suggest that the inclusion of labor market status variables reduces the education coefficient by 10 percentage points. In our case inclusion of all other covariates reduces the coefficient of years of schooling by almost half (Table 1b, model 1 and model 5).

\subsection{Alcohol Consumption}

According the OECD (2010) Health Data set, only 1.5 per cent of adult population in Turkey consumes alcohol. This amount is very low compared to other OECD countries. The low percentage of alcohol consumption in Turkey is most probably due to religious traditions which 
prohibit alcohol consumption. Similarly, in THS the proportion of daily alcohol drinkers is very low, less than one percent (0.5 per cent, 0.4 per cent and 0.2 per cent in 2008, 2010 and 2012 respectively). In order to capture the variation in alcohol consumption, we combine the daily and occasional alcohol drinkers and call them as "alcohol drinkers" in our analysis. Table 2a reports the descriptive statistics for alcohol consumption. We refer to an individual as alcohol drinker if the individual states that he/she currently consumes alcohol regularly or occasionally. We see that average years of schooling is higher among alcohol drinkers (9.63 years) than among non-alcohol consumers (6.14 years). The occurrence of alcohol consumption increases as level of education increases and it is highest among the university or higher graduates. Percentage of alcohol drinkers is higher among males than among females. Alcohol consumers are younger than the non-alcohol consumers and the urban residents consume more than the rural residents. Regarding the marital status, we note that the percentage of alcohol drinkers is higher among singles than the married and widowed/divorced. The fraction of alcohol drinkers among employed and unemployed are equal and significantly higher than that of the inactive. Lastly, household income is significantly higher among alcohol consumers.

Table $2 \mathrm{~b}$ presents the marginal effects (in percentages) from probit estimation results. Our results indicate that there is a positive relationship between education level and alcohol consumption. We find that the probability of alcohol consumption increases by 0.0236 per cent when schooling increases by one year. We replicate our model by adding education dummies in place of years of schooling. The marginal effects (in percentages) (see also Figure 1) from this regression are reported in Table 2c. Table $2 \mathrm{c}$ shows that the probability of alcohol consumption increases with education level. It increases by 0.0564 per cent for non-graduates, 0.1259 per cent for primary school graduates 0.1691 per cent for middle school graduates by 0.1795 percent for high school graduates and 0.2091 percent for the individuals with university or higher degree, compared to illiterates. This result can be attributed to two facts: First, highly educated people participate in social activities more than the low educated due to their larger social networks and they tend to consume more alcohol during the social activities. Second, as Kenkel (1991) suggests, more educated people may know that some drink is good for health, hence they drink more than the others. 
We next consider the rest of the covariates. We see that males tend to consume more alcohol than females. Like in the case of smoking, the relationship between alcohol consumption and age is an inverted U-shaped. Alcohol consumption increases with age and roughly at age 48 alcohol consumption reaches a maximum after which it starts to decrease. The urban dwellers consume significantly more alcohol than the rural ones albeit it loses its significance when we control for income. The probability of alcohol consumption of married and single people are significantly less than that of widowed/divorced. Moreover, being in labor force also positively and significantly affects the probability of alcohol consumption. The probability of alcohol consumption increases by approximately 0.04 percent and 0.06 per cent for the employed and unemployed respectively compared to an inactive person. This finding may again be attributed to larger social networks for the employed and the anxiety/stress for the unemployed. Finally, we find that an increase in log of household income leads to 0.0390 per cent increase in probability of alcohol consumption.

In short, our results are consistent with Kenkel (1991) as well as Ettner (1996) who suggest higher probability of light drinking among higher socioeconomic groups. However, Cutler and Llearas-Muney (2010) find a negative association between probability of being heavy alcohol drinker and education It is important to note that the number of heavy drinkers in our data set is very small for a separate analysis. Thus; our results mostly explain the variations in light alcohol consumption by education and other determinants like Kenkel and Ettner.

\subsection{Fruit and Vegetable Consumption}

Fruit and vegetables are necessary for healthy life. Sufficient daily consumption of fruit and vegetables could prevent several kinds of diseases, such as cardiovascular diseases, certain cancers and diabetes (Hung et al. 2004). Hence, it is important to investigate the variation in fruit and vegetable consumption. We define an individual as a regular fruit and vegetable consumer if the individual reports that he/she consumes fruits, vegetables and/or their juice at least once a week. Table 3a presents the descriptive statistics. We observe that years of schooling is higher among fruit and vegetable consumers than non-consumers. The prevalence of regular fruit and vegetable consumption is the highest among individuals who have university or higher degree compared to other education groups. The fruit and vegetable consumption is higher among males. Fruit and vegetable consumers are younger and urban residents consume more fruits and 
vegetables than rural ones. Singles consume more fruits and vegetables than the married and widowed/divorced. Fruit and vegetable consumption is similar among the employed unemployed and inactive. Finally, household income is somewhat higher among the regular fruit and vegetable consumers.

Table $3 \mathrm{~b}$ presents the marginal effects (in percentages) from probit estimation results We find that fruit and vegetable consumption is positively and significantly associated with education level. We observe that the probability of fruit and vegetable consumption increases by 0.0142 percent when years of schooling increase by a year. We re-estimate the regression by dropping

years of schooling and including education level dummies in place. Marginal effects (in percentages) (see also Figure 1) from these probit estimation results are reported in Table 3c. We again find a positive relationship between fruit and vegetable consumption and education level. the probability of alcohol consumption increases with education level. It increases by 0.0358 per cent for non-graduates, 0.0595 per cent for primary school graduates 0.0812 per cent for middle school graduates by 0.0856 percent for high school graduates and 0.0881 percent for the individuals with university or higher degree compared to illiterates. We can conclude that people with higher levels of education are better informed about the benefits of fruit and vegetable consumption.

We now consider the rest of the covariates. We observe that males are more likely to consume fruits and vegetables than females. The probability of fruit and vegetable consumption and age has a U-shape relationship indicating an initial decline up to age 56 and an increase afterwards. Urban residents tend to consume more fruit and vegetables than rural ones. Singles tend to consume more fruits and vegetables than the widowed/divorced while the marginal effect for the married is not significantly different from the latter group. the probability of consuming fruit and vegetables for the employed and unemployed individuals is significantly smaller than that of the inactive. Finally, as household income increases the probability of consuming fruits and vegetables also increases.

\subsection{Exercise}

Regular physical activity is an important factor that improves the individual's health. It could prevent many diseases such as heart disease and stroke, high blood pressure, diabetes, obesity, 
back pain, osteoporosis, and can improve the psychological condition of the individual (Fletcher et al., 1996). Therefore, it is important to examine the variation in physical activity of the individuals. In THS we observe the respondent's frequency of exercise, divided into three categories: High level exercise (such as aerobic exercise or working in construction sector), medium level exercise (such as riding a bicycle or house work) and low level exercise (such as walking). If the individual does not experience one of these activities at least 10 minutes in the reference week, then we assume that individual does not make regular physical activity. Table $4 \mathrm{a}$ presents the descriptive statistic for exercise behavior. Individuals who exercise regularly have higher years of schooling and prevalence of exercise is higher among university graduates and among males. Individuals who exercise regularly are younger. Urban residents exercise slightly more than the rural ones. Married and single individuals exercise more than the widowed/divorced. Employed people exercise more than the unemployed and the inactive. Finally, average household income is slightly higher among individuals who exercise regularly.

Table $4 \mathrm{~b}$ shows the marginal effects (in percentages) from probit estimation results for exercise behavior. We find that regular exercise is positively and significantly associated with education level. The probability of exercise increases by 0.0265 percent when years of schooling increase by a year. We re-estimate the regression by dropping years of schooling and including education level dummies in place. Marginal effects (in percentages) (see also Figure 1) from these probit estimation results are reported in Table 4c. We again find a positive relationship between exercise and education level. The probability of exercise increases with education level. It increases by 0.0880 per cent for non-graduates, 0.1157 per cent for primary school graduates 0.1494 per cent for middle school graduates by 0.1510 percent for high school graduates and 0.1557 percent for the individuals with university or higher degree compared to illiterates. Our results are consistent with previous literature findings. For instance, the studies for developed countries such as Kenkel (1991) and Lantz et al. (2001) in the USA also find a positive relationship between schooling and exercise.

We now consider the rest of the covariates. Males tend to exercise than the females. The probability of exercise and age has a concave relationship: Individuals are more likely to exercise as they get older, but roughly at age 46 , probability of exercise starts to decrease. Rural residents 
tend to exercise more than the urban ones. The probability of exercise is significantly higher for the married people than for the widowed/divorced, whereas exercise behavior of single individuals do not significantly differ from that of widowed/divorced. Employed individuals tend to exercise significantly more than inactive while the exercise behavior of the unemployed is not significantly different from that of the inactive. The probability of exercise increases by 0.0411 percent if the individual is employed. These results are consistent with our expectations, since employed people are physically more active than the unemployed or the inactive. Finally, our results suggest that household income does not significantly affect the exercise behavior of the individual.

\subsection{Body Mass Index (BMI)}

Obesity is an increasing health problem in Turkey. It is important to analyze the determinants of obesity as it is a major source of certain diseases such as cardiovascular diseases, diabetes, and joint problems (Stewart et al., 2009). OECD (2010) Health Data indicate that 21 percent of females and 13.2 percent of males in Turkey were obese in 2010. World Bank (2008) reported that the adoption of Western diets high in refined carbohydrates, saturated fats and sugars and a more sedentary lifestyle are major contributors to the increase in overweight and chronic diseases in Turkey. BMI is used as a tool for determining if an individual is overweight or obese. An individual is considered as obese if his/her BMI is greater than 30, overweight if his/her BMI is greater than 25 and underweight if his/her BMI is under 18.5 according to World Health Organization (WHO) criteria. The BMI in our study is computed from the self-reported height (in centimeters) and weight (in kilograms) in the THS. We calculate individual's BMI by dividing the self-reported weight of respondent (in kilograms) to the square of the self-reported height in meters.

There are few studies that examine the determining factors of obesity in Turkey. These studies include Erem et al. (2004) and Hatemi et al. (2003). Erem et al. suggest that demographic factors such as marital status, number of births and household income as well as giving up smoking and alcohol consumption lead to higher BMI levels. On the contrary, they find that level of education, tobacco use, and higher physical activity is positively associated with lower BMI. Finally, they find that hypertension also promotes obesity. Hatemi et al. (2003) conclude that frequency of 
being obese or overweight is very high in Turkey and there is a positive relationship between higher BMI and blood pressure for both men and women. Yumuk (2005) concludes that men tend to be overweight more than women, however, women are more likely to be obese than men.

Table 5a presents the descriptive statistics for five different BMI groups as well as the statistics for BMI for the whole sample. Accordingly, average years of schooling is lower among obese individuals. The prevalence of obesity is higher among illiterate and non-graduate individuals. Females are more obese than males and males are more overweight than females. Obese individuals are slightly older. There is no difference in the weight ranges of urban and rural residents. The occurrence of being overweight is higher among married and prevalence of obesity is higher among widowed/divorced individuals. Prevalence of being obese is higher among inactive individuals. Lastly, we observe that household income is slightly higher among overweight individuals.

Table $5 \mathrm{~b}$ presents the OLS estimation results where the dependent variable is the individual's BMI. We find that an increase in years of schooling results with normal ranges of BMI. This result is similar to the results of the previous literature such as Kemptner et al. (2011), Brunello et al. (2011), Webbink et al (2010), Cutler and Llearas-Muney (2010) and Lantz et al. (2001). We find that one year increase in years of schooling leads to 0.11 unit decrease in individual's BMI level. Table 5c reports OLS estimation results where we drop years of schooling and add dummy variables for education levels instead (see also Figure 1). Our results suggest that BMI levels of illiterate and non-graduate people do not significantly differ from each other when we add logarithms of household income into our analysis. For other education groups, we observe that as education level increases, the individual's BMI level decreases. The BMI level decreases even more (by 1.72 units) if the individual has university or higher degree. This result suggests that more educated people are better informed about the risks of overweight or obesity.

We now consider the rest of the covariates. Females have significantly higher levels of BMI than males. However, when we add the logarithm of household income into our analysis, we see that BMI levels of males and females do not significantly differ from each other. BMI level increases with age at a decreasing rate. Urban residents have higher BMI levels than rural ones. Our results indicate that the BMI levels of married and single individuals are significantly lower 
from that of the widowed/divorced people. Next, we find that both employed and unemployed individuals have lower BMI levels than the inactive. This may be due to the more sedentary lifestyles of inactive people. Finally, we find that as household income increases so does BMI.

\section{Conclusion}

This paper investigates the determinants of health behaviors in Turkey in particular with respect to education. This study is the first study that analyzes the variations in health behaviors in Turkey in one study. The health behaviors considered are smoking, alcohol consumption, fruit and vegetable consumption, exercise and individual's BMI. We considered education as well as demographic factors, such as gender, age, the region where the individual lives (urban/rural), employment status of the individual and the household income. In conclusion, education is found to be an important factor that could reduce the probability of risky health behaviors in Turkey. Unlike the previous studies in developed countries, the probability of smoking increases with education. However, the effect of university or more education is smaller than the effect of lower levels of schooling. Thus the results indicate that smoking is positively associated with education at all levels with a decreasing effect with the level of education. This result indicates that smoking is a serious public health problem in Turkey at all levels of education. Policy makers must pay attention to this problem. Higher educated individuals clearly eat more fruits and vegetables compared to less educated and illiterate. We also find that higher educated individuals exercise more. Next, we observe that higher educated individuals clearly have BMI levels in the normal range compared to less educated. The only exception is the alcohol consumption where higher educated individuals tend to consume more alcohol in Turkey than the less educated.

As a result we can say that higher education may be a factor that heightens sensitivity towards adverse effects of risky behaviors except that of alcohol. Thus, policy makers should pay more attention to increasing education levels. Further, it is worthy to note that income does not significantly influence tobacco consumption but it significantly increases alcohol consumption, fruit and vegetable consumption and BMI while income does not affect the probability of exercise. Males tend to consume more tobacco and alcohol than females. They are also more likely to consume fruits and vegetables and exercise more than females. Finally, BMI of females is higher than that of males. 


\section{References}

Bolin, K. "Health Production." Oxford Handbook of Health Economics. Ed. S. Glied and P.C. Smith. New York: Oxford University Press, 2011: 95-123. Print.

Brunello, G., D. Fabbri, and M. Fort (2013) "The Causal Effect of Education on Body Mass: Evidence from Europe," Journal of Labor Economics 31(1): 195-223.

Brunello, G., M. Fort, N. Schneeweis and R. Winter-Ebmer (2011) "The Causal Effect of Education on Health: What is the Role of Health Behaviors?" CEPR Discussion Paper No. DP8707.

Carbone, J. C., S. Kverndokk, and O. J. Røgeberg (2005) "Smoking, Health, Risk, and Perception," Journal of Health Economics 24(4): 631-653.

Case, A. and C. Paxson (2005) "Sex Differences in Morbidity and Mortality," Demography 42(2): 189-214.

Cawley, J., and C. J. Ruhm (2011) "The Economics of Risky Health Behaviors," Handbook of Health Economics 2: 97-153.

Chaloupka, F. J., and K. E. Warner (2000) "The Economics of Smoking," Handbook of Health Economics 1: 1539-1627.

Cutler, D. M., E. L. Glaeser, and J. M. Shapiro (2003) "Why Have Americans Become More Obese?" The Journal of Economic Perspectives 17(3): 93-118.

Cutler, D. M., and E. L. Glaeser (2005) "What Explains Differences in Smoking, Drinking, and Other Health-Related Behaviors?" The American Economic Review 95(2): 238-242.

Cutler, D. M., Lleras-Muney, A. (2008) "Education and Health: Evaluating Theories and Evidence,” In: James, S.H., Schoeni, R.F., Kaplan, G.A., Pollack, H. (Eds), Making Americans Healthier: Social and Economic Policy as Health Policy. Russel Sage Foundation, New York.

Cutler, D. M. and A. Lleras-Muney (2010) "Understanding Differences in Health Behaviors by Education," Journal of Health Economics 29(1):1-28. 
Cutler, D. M., A. Lleras-Muney, and T. Vogl. "Socioeconomic Status and Health: Dimensions and Mechanisms," Oxford Handbook of Health Economics. Ed. S. Glied and P.C. Smith. New York: Oxford University Press, 2011: 124-163. Print.

De Walque, D. (2007) "Does Education Affect Smoking Behaviors?: Evidence Using the Vietnam Draft as an Instrument for College Education," Journal of health economics 26(5): 877895.

Erem, C., et al. (2004) "Prevalence of Obesity and Associated Risk Factors in a Turkish Population (Trabzon City, Turkey)," Obesity Research 12(7): 1117-1127.

Erbaydar, T., et al. (2005) "Influence of Social Environment in Smoking among Adolescents in Turkey," The European Journal of Public Health 15(4): 404-410.

Ettner, S. L. (1996) "New Evidence on the Relationship between Income and Health," Journal of Health Economics 15(1): 67-85.

Fletcher, G. F., et al. (1996) "Statement on Exercise: Benefits and Recommendations for Physical Activity Programs for All Americans A Statement for Health Professionals by the Committee on Exercise and Cardiac Rehabilitation of the Council on Clinical Cardiology, American Heart Association," Circulation 94(4): 857-862.

Fuchs, V. R. (2004) "Reflections on the Socio-Economic Correlates of Health," Journal of Health Economics 23(4): 653-661.

García, V. J., and C. Quintana-Domeque (2009) "Income and Body Mass Index in Europe," Economics \& Human Biology 7(1): 73-83.

Grossman, M., (1972) "On the Concept of Health Capital and the Demand for Health," Journal of Political Economy 80(2): 223-255.

Grossman, M., "The Human Capital Model," Handbook of Health Economics Vol.1. Ed. A.J. Culyer and J.P.Newhouse. Amsterdam: Elsevier, 2000. 348-408. Print.

Grossman, M., (2004) "The Demand for Health, 30 Years Later: A Very Personal Retrospective and Prospective Reflection," Journal of Health Economics 23(4): 629-636. 
Gruber, J., and M. Frakes (2006) "Does Falling Smoking Lead to Rising Obesity?" Journal of Health economics 25(2): 183-197.

Hatemi, H., et al. (2003) "Prevalence of Overweight and Obesity in Turkey," Metabolic Syndrome and Related Disorders 1(4): 285-290.

Hung, H.C., et al. (2004) "Fruit and Vegetable Intake and Risk of Major Chronic Disease," Journal of the National Cancer Institute 96(21): 1577-1584.

Idler, E. L. and Y. Benyamini (1997) "Self-Rated Health and Mortality: A Review of TwentySeven Community Studies," Journal of Health and Social Behavior 38(1): 21-37.

Kemptner, D., H. Jürges and S. Reinhold. (2011) "Changes in Compulsory Schooling and the Causal Effect of Education on Health: Evidence from Germany," Journal of Health Economics 30(2):340-354.

Kenkel, D. S. (1991) "Health Behavior, Health Knowledge, and Schooling," Journal of Political Economy 99(2): 287-305.

Kocabas, A., et al. (1994) "Smoking Patterns at Different Medical Schools in Turkey," Tobacco Control 3(3): 228-235.

Lantz, P. M., et al. (1998) "Socioeconomic Factors, Health Behaviors, and Mortality," JAMA: The Journal of the American Medical Association 279(21): 1703-1708.

Lantz, P. M., et al. (2001) "Socioeconomic Disparities in Health Change in a Longitudinal Study of US Adults: The Role of Health-Risk Behaviors," Social Science \& Medicine 53(1): 29-40.

Lleras-Muney, A., (2005) "The Relationship between Education and Adult Mortality in the U.S," Review of Economic Studies 72(1): 189-221.

Metintaş, S., et al. (1998) "Smoking Patterns of University Students in Eskişehir, Turkey," Public Health 112(4): 261-264.

Mokdad, A. H., J. S. Marks, D. F. Stroup, and J. L. Gerberding (2004) “Actual Causes of Death in the United States 2000," Journal of American Medical Association 291(10): 1238-1245. 
Mullahy, J. (1997) "Instrumental-Variable Estimation of Count Data Models: Applications to Models of Tobacco Smoking Behavior," Review of Economics and Statistics 79(4): 586-593.

Organization for Economic Cooperation and Development (OECD) (2010) Health Data Set (http://stats.oecd.org)

Reijneveld, S. A. (2002) "Neighbourhood Socioeconomic Context and Self Reported Health and Smoking: a Secondary Analysis of Data on Seven Cities," J Epidemiol Community Health 56: 935-942.

Stewart, S. T., D. M. Cutler, and A. B. Rosen (2009) "Forecasting the Effects of Obesity and Smoking on US Life Expectancy," New England Journal of Medicine 361(23): 2252-2260.

Tansel, A. (1993) "Tobacco Demand, Health Scares and Education in Turkey," Applied Economics 25(4): 521-529.

Webbink, D., N. G. Martin and P. M. Visscher (2010) "Does Education Reduce the Probability of Being Overweight?" Journal of Health Economics 29(1):29-38.

Worldbank (2008) World Bank Report.

(http://siteresources.worldbank.org/NUTRITION/Resources/2818461271963823772/Turkey.pdf)

Yumuk, V. D. (2005) "Prevalence of Obesity in Turkey," Obesity Reviews 6(1): 9-10. 
Table 1a. Descriptive Statistics for Smoking

\begin{tabular}{|c|c|c|c|}
\hline Variable & Smoker & Non-Smoker & Total \\
\hline Male* & $\begin{array}{l}0.43 \\
(0.49)\end{array}$ & $\begin{array}{l}0.57 \\
(0.49)\end{array}$ & 1.00 \\
\hline Female* & $\begin{array}{l}0.17 \\
(0.38)\end{array}$ & $\begin{array}{l}0.83 \\
(0.38)\end{array}$ & 1.00 \\
\hline Age (Years) & $\begin{array}{l}43.32 \\
(12.04)\end{array}$ & $\begin{array}{l}49.51 \\
(15.47)\end{array}$ & $\begin{array}{l}47.74 \\
(14.83)\end{array}$ \\
\hline Age-Squared & $\begin{array}{l}2022 \\
(1169)\end{array}$ & $\begin{array}{l}2690 \\
(1638)\end{array}$ & $\begin{array}{l}2499 \\
(1549)\end{array}$ \\
\hline Urban* & $\begin{array}{l}0.31 \\
(0.46)\end{array}$ & $\begin{array}{l}0.69 \\
(0.46)\end{array}$ & 1.00 \\
\hline Rural* & $\begin{array}{l}0.22 \\
(0.42)\end{array}$ & $\begin{array}{l}0.78 \\
(0.42)\end{array}$ & 1.00 \\
\hline \multicolumn{4}{|c|}{ Marital Status } \\
\hline Married* & $\begin{array}{l}0.29 \\
(0.45)\end{array}$ & $\begin{array}{l}0.71 \\
(0.45)\end{array}$ & 1.00 \\
\hline Single* & $\begin{array}{l}0.36 \\
(0.48)\end{array}$ & $\begin{array}{l}0.64 \\
(0.48)\end{array}$ & 1.00 \\
\hline Widowed/Divorced* & $\begin{array}{l}0.20 \\
(0.40)\end{array}$ & $\begin{array}{l}0.80 \\
(0.40)\end{array}$ & 1.00 \\
\hline \multicolumn{4}{|c|}{ Education } \\
\hline Years of Schooling & $\begin{array}{l}7.78 \\
(4.00)\end{array}$ & $\begin{array}{l}6.21 \\
(4.58)\end{array}$ & $\begin{array}{l}6.66 \\
(4.48)\end{array}$ \\
\hline $\begin{array}{l}\text { Years of Schooling- } \\
\text { Squared }\end{array}$ & $\begin{array}{l}76.57 \\
(70.75)\end{array}$ & $\begin{array}{l}59.69 \\
(72.23)\end{array}$ & $\begin{array}{l}64.51 \\
(72.21)\end{array}$ \\
\hline Illiterate* & $\begin{array}{l}0.08 \\
(0.27)\end{array}$ & $\begin{array}{l}0.92 \\
(0.27)\end{array}$ & 1.00 \\
\hline Non-Graduate* & $\begin{array}{l}0.16 \\
(0.36)\end{array}$ & $\begin{array}{l}0.84 \\
(0.36)\end{array}$ & 1.00 \\
\hline Primary School* & $\begin{array}{l}0.29 \\
(0.45)\end{array}$ & $\begin{array}{l}0.71 \\
(0.45)\end{array}$ & 1.00 \\
\hline Middle School* & $\begin{array}{l}0.42 \\
(0.49)\end{array}$ & $\begin{array}{l}0.58 \\
(0.49)\end{array}$ & 1.00 \\
\hline High School* & $\begin{array}{l}0.40 \\
(0.49)\end{array}$ & $\begin{array}{l}0.60 \\
(0.49)\end{array}$ & 1.00 \\
\hline University+* & $\begin{array}{l}0.30 \\
(0.46)\end{array}$ & $\begin{array}{l}0.70 \\
(0.45)\end{array}$ & 1.00 \\
\hline \multicolumn{4}{|c|}{ Labor Market Status } \\
\hline Employed* & $\begin{array}{l}0.41 \\
(0.49)\end{array}$ & $\begin{array}{l}0.59 \\
(0.49)\end{array}$ & 1.00 \\
\hline Unemployed* & $\begin{array}{l}0.51 \\
(0.50)\end{array}$ & $\begin{array}{l}0.49 \\
(0.50)\end{array}$ & 1.00 \\
\hline Out of Labor Force* & $\begin{array}{l}0.18 \\
(0.39)\end{array}$ & $\begin{array}{l}0.82 \\
(0.39)\end{array}$ & 1.00 \\
\hline $\begin{array}{l}\text { Log Household Income } \\
\text { (TL) }\end{array}$ & $\begin{array}{l}7.05 \\
(0.58)\end{array}$ & $\begin{array}{l}6.97 \\
(0.60)\end{array}$ & $\begin{array}{l}7.00 \\
(0.60)\end{array}$ \\
\hline $\begin{array}{l}\text { Number of Observations } \\
\text { in } 2010\end{array}$ & 3469 & 8311 & 11780 \\
\hline $\begin{array}{l}\text { Number of Observations } \\
\text { in } 2012\end{array}$ & 6446 & 16490 & 22936 \\
\hline Total Observations & 9915 & 24801 & 34716 \\
\hline
\end{tabular}


Table 1b. Marginal Effects from Probit Estimation Results for Smoking with Years of Schooling (\%)

\begin{tabular}{|c|c|c|c|c|c|}
\hline Variable & $(1)$ & (2) & (3) & (4) & $(5)$ \\
\hline $\begin{array}{l}\text { Years of } \\
\text { Schooling }\end{array}$ & $\begin{array}{l}6.05 * * * \\
(0.20)\end{array}$ & $\begin{array}{l}3.72 * * * \\
(0.21)\end{array}$ & $\begin{array}{l}3.82 * * * \\
(0.21)\end{array}$ & $\begin{array}{l}3.87 * * * \\
(0.21)\end{array}$ & $\begin{array}{l}3.84 * * * \\
(0.21)\end{array}$ \\
\hline $\begin{array}{l}\text { Years of } \\
\text { Schooling } \\
\text { Square }\end{array}$ & $\begin{array}{l}-0.30 * * * \\
(0.01)\end{array}$ & $\begin{array}{l}-0.21 * * * \\
(0.01)\end{array}$ & $\begin{array}{l}-0.21 * * * \\
(0.01)\end{array}$ & $\begin{array}{l}-0.22 * * * \\
(0.01)\end{array}$ & $\begin{array}{l}-0.22^{* * * *} \\
(0.01)\end{array}$ \\
\hline Male & $\begin{array}{l}20.60 * * * \\
(0.43)\end{array}$ & $\begin{array}{l}22.90 * * * \\
(0.43)\end{array}$ & $\begin{array}{l}23.92 * * * \\
(0.43)\end{array}$ & $\begin{array}{l}20.83 * * * \\
(0.53)\end{array}$ & $\begin{array}{l}21.00 * * * \\
(0.53)\end{array}$ \\
\hline $\operatorname{Age}\left(x_{10}^{-1}\right)$ & & $\begin{array}{l}8.77 * * * \\
(1.18)\end{array}$ & $\begin{array}{l}9.53 * * * \\
(1.21)\end{array}$ & $\begin{array}{l}8.60 * * * \\
(1.19)\end{array}$ & $\begin{array}{l}8.56 * * * \\
(1.21)\end{array}$ \\
\hline $\begin{array}{l}\text { Age } \\
\text { Square }\left(\times_{10}^{-3}\right)\end{array}$ & & $\begin{array}{l}-13.96^{* * * *} \\
(1.18)\end{array}$ & $\begin{array}{l}-15.32 * * * \\
(1.21)\end{array}$ & $\begin{array}{l}-13.55 * * * \\
(1.20)\end{array}$ & $\begin{array}{l}-13.59 * * * \\
(1.21)\end{array}$ \\
\hline Urban & & $\begin{array}{l}5.42 * * * \\
(0.52)\end{array}$ & $\begin{array}{l}5.13 * * * \\
(0.53)\end{array}$ & $\begin{array}{l}5.59 * * * \\
(0.53)\end{array}$ & $\begin{array}{l}5.61 * * * \\
(0.55)\end{array}$ \\
\hline \multicolumn{6}{|c|}{ Marital Status } \\
\hline Married & & & $\begin{array}{l}-10.96^{* * * *} \\
(0.86)\end{array}$ & $\begin{array}{l}-10.07 * * * \\
(0.86)\end{array}$ & $\begin{array}{l}-10.28 * * * \\
(0.86)\end{array}$ \\
\hline Single & & & $\begin{array}{l}-11.57 * * * \\
(1.19)\end{array}$ & $\begin{array}{l}-11.52 * * * \\
(1.19)\end{array}$ & $\begin{array}{l}-11.78^{* * *} \\
(1.21)\end{array}$ \\
\hline \multicolumn{6}{|c|}{ Labor Force Status } \\
\hline Employed & & & & $\begin{array}{l}5.43 * * * \\
(0.58)\end{array}$ & $\begin{array}{l}5.31 * * * \\
(0.59)\end{array}$ \\
\hline Unemployed & & & & $\begin{array}{l}11.05^{* * *} \\
(1.31)\end{array}$ & $\begin{array}{l}10.97 * * * \\
(1.34)\end{array}$ \\
\hline $\begin{array}{l}\text { Log } \\
\text { Household } \\
\text { Income }\end{array}$ & & & & & $\begin{array}{l}0.36 \\
(0.47)\end{array}$ \\
\hline Dummy12 & $\begin{array}{l}-2.38 * * * \\
(0.48)\end{array}$ & $\begin{array}{l}-2.31 * * * \\
(0.47)\end{array}$ & $\begin{array}{l}-2.36 * * * \\
(0.47)\end{array}$ & $\begin{array}{l}-2.28 * * * \\
(0.47)\end{array}$ & $\begin{array}{l}-2.35 * * * \\
(0.48)\end{array}$ \\
\hline Pseudo R2 & 0.09 & 0.12 & 0.12 & 0.13 & 0.13 \\
\hline $\begin{array}{l}\text { (-) Log- } \\
\text { Likelihood }\end{array}$ & 18802 & 18240 & 18163 & 18102 & 17916 \\
\hline $\mathbf{N}$ & 34716 & 34716 & 34716 & 34716 & 34350 \\
\hline
\end{tabular}

Source:Authors' computations using 2010-2012 Turkish Health Survey

Notes:

$(1)^{* * *}$ indicates $1 \%$ level of significance, $* *$ indicates $5 \%$ level of significance, $*$ indicates $10 \%$ level of significance.

(2) Robust standard errors are shown in paranthesis.

(3) Marginal effects are computed at the means of the variables 
Table 1c. Marginal Effects from Probit Estimation Results for Smoking with Education Levels (\%)

\begin{tabular}{|c|c|c|c|c|c|}
\hline Variable & (1) & $(2)$ & (3) & (4) & $(5)$ \\
\hline \multicolumn{6}{|c|}{ Education } \\
\hline $\begin{array}{l}\text { Non- } \\
\text { Graduate }\end{array}$ & $\begin{array}{l}8.50 * * * \\
(1.34)\end{array}$ & $\begin{array}{l}6.27 * * * \\
(1.33)\end{array}$ & $\begin{array}{l}6.75 * * * \\
(1.32)\end{array}$ & $\begin{array}{l}6.84 * * * \\
(1.31)\end{array}$ & $\begin{array}{l}6.66^{* * * *} \\
(1.32)\end{array}$ \\
\hline $\begin{array}{l}\text { Primary } \\
\text { School }\end{array}$ & $\begin{array}{l}20.16^{* * * *} \\
(0.91)\end{array}$ & $\begin{array}{l}10.98^{* * *} \\
(0.94)\end{array}$ & $\begin{array}{l}11.71 * * * \\
(0.95)\end{array}$ & $\begin{array}{l}11.67 * * * \\
(0.94)\end{array}$ & $\begin{array}{l}11.50 * * * \\
(0.95)\end{array}$ \\
\hline $\begin{array}{l}\text { Middle } \\
\text { School }\end{array}$ & $\begin{array}{l}29.45^{* * * *} \\
(1.09)\end{array}$ & $\begin{array}{l}17.20^{* * * *} \\
(1.14)\end{array}$ & $\begin{array}{l}17.81 * * * \\
(1.14)\end{array}$ & $\begin{array}{l}17.62 * * * \\
(1.14)\end{array}$ & $\begin{array}{l}17.27 * * * \\
(1.16)\end{array}$ \\
\hline High School & $\begin{array}{l}28.08 * * * \\
(1.01)\end{array}$ & $\begin{array}{l}14.74 * * * \\
(1.08)\end{array}$ & $\begin{array}{l}15.34 * * * \\
(1.08)\end{array}$ & $\begin{array}{l}14.99 * * * \\
(1.08)\end{array}$ & $\begin{array}{l}14.63 * * * \\
(1.12)\end{array}$ \\
\hline University+ & $\begin{array}{l}19.47 * * * \\
(1.07)\end{array}$ & $\begin{array}{l}6.29 * * * \\
(1.14)\end{array}$ & $\begin{array}{l}7.11 * * * \\
(1.14)\end{array}$ & $\begin{array}{l}5.89 * * * \\
(1.15)\end{array}$ & $\begin{array}{l}5.42 * * * \\
(1.22)\end{array}$ \\
\hline Male & $\begin{array}{l}20.61 * * * \\
(0.43)\end{array}$ & $\begin{array}{l}22.90 * * * \\
(0.43)\end{array}$ & $\begin{array}{l}23.90 * * * \\
(0.43)\end{array}$ & $\begin{array}{l}20.79 * * * \\
(0.53)\end{array}$ & $\begin{array}{l}20.96 * * * \\
(0.53)\end{array}$ \\
\hline $\operatorname{Age}\left(\mathbf{x 1 0}^{-1}\right)$ & & $\begin{array}{l}9.41 * * * \\
(1.18)\end{array}$ & $\begin{array}{l}10.05 * * * \\
(1.20)\end{array}$ & $\begin{array}{l}9.15^{* * * *} \\
(1.19)\end{array}$ & $\begin{array}{l}9.09 * * * \\
(1.20)\end{array}$ \\
\hline $\begin{array}{l}\text { Age } \\
\text { Square }\left(\times 10^{-3}\right)\end{array}$ & & $\begin{array}{l}-14.59 * * * \\
(1.18)\end{array}$ & $\begin{array}{l}-15.83^{* * *} \\
(1.21)\end{array}$ & $\begin{array}{l}-14.08^{* * * *} \\
(1.20)\end{array}$ & $\begin{array}{l}-14.10^{* * * *} \\
(1.21)\end{array}$ \\
\hline Urban & & $\begin{array}{l}5.30 * * * \\
(0.53)\end{array}$ & $\begin{array}{l}5.04 * * * \\
(0.52)\end{array}$ & $\begin{array}{l}5.49 * * * \\
(0.53)\end{array}$ & $\begin{array}{l}5.51 * * * \\
(0.54)\end{array}$ \\
\hline \multicolumn{6}{|c|}{ Marital Status } \\
\hline Married & & & $\begin{array}{l}-10.76^{* * * *} \\
(0.86)\end{array}$ & $\begin{array}{l}-9.85^{* * * *} \\
(0.86)\end{array}$ & $\begin{array}{l}-10.07 * * * \\
(0.86)\end{array}$ \\
\hline Single & & & $\begin{array}{l}-11.49 * * * \\
(1.19)\end{array}$ & $\begin{array}{l}-11.43 * * * \\
(1.19)\end{array}$ & $\begin{array}{l}-11.70 \text { *** } \\
(1.20)\end{array}$ \\
\hline \multicolumn{6}{|c|}{ Labor Force Status } \\
\hline Employed & & & & $\begin{array}{l}5.48 * * * \\
(0.58)\end{array}$ & $\begin{array}{l}5.36 * * * \\
(0.58)\end{array}$ \\
\hline Unemployed & & & & $\begin{array}{l}11.07 * * * \\
(1.31)\end{array}$ & $\begin{array}{l}10.99 * * * \\
(1.34)\end{array}$ \\
\hline $\begin{array}{l}\text { Log } \\
\text { Household } \\
\text { Income }\end{array}$ & & & & & $\begin{array}{l}0.39 \\
(0.46)\end{array}$ \\
\hline Dummy12 & $\begin{array}{l}-2.42 * * * \\
(0.48)\end{array}$ & $\begin{array}{l}-2.34 * * * \\
(0.47)\end{array}$ & $\begin{array}{l}-2.38 * * * \\
(0.47)\end{array}$ & $\begin{array}{l}-2.31 * * * \\
(0.47)\end{array}$ & $\begin{array}{l}-2.37 * * * \\
(0.48)\end{array}$ \\
\hline Pseudo R2 & 0.10 & 0.12 & 0.13 & 0.13 & 0.13 \\
\hline $\begin{array}{l}\text { (-) Log- } \\
\text { Likelihood }\end{array}$ & 18791 & 18227 & 18152 & 18091 & 17905 \\
\hline $\mathbf{N}$ & 34716 & 34716 & 34716 & 34716 & 34350 \\
\hline
\end{tabular}

Source:Authors' computations using 2010-2012 Turkish Health Survey

Notes: (1)*** indicates $1 \%$ level of significance, **indicates $5 \%$ level of significance, *indicates $10 \%$ level of significance.

(2) Robust standard errors are shown in paranthesis.

(3) Marginal effects are computed at the means of the variables 
Table 2a. Descriptive Statistics for Alcohol Consumption

\begin{tabular}{|c|c|c|c|}
\hline Variable & Alcohol Consumer & $\begin{array}{l}\text { Non-Alcohol } \\
\text { Consumer }\end{array}$ & Total \\
\hline Male* & $\begin{array}{l}0.20 \\
(0.40)\end{array}$ & $\begin{array}{l}0.80 \\
(0.40)\end{array}$ & 1.00 \\
\hline Female* & $\begin{array}{l}0.04 \\
(0.21)\end{array}$ & $\begin{array}{l}0.96 \\
(0.21)\end{array}$ & 1.00 \\
\hline Age (Years) & $\begin{array}{l}43.52 \\
(12.00)\end{array}$ & $\begin{array}{l}47.91 \\
(15.06)\end{array}$ & $\begin{array}{l}47.41 \\
(14.81)\end{array}$ \\
\hline Age-Squared & $\begin{array}{l}2038 \\
(1150)\end{array}$ & $\begin{array}{l}2522 \\
(1577)\end{array}$ & $\begin{array}{l}2466 \\
(1541)\end{array}$ \\
\hline Urban* & $\begin{array}{l}0.13 \\
(0.34)\end{array}$ & $\begin{array}{l}0.87 \\
(0.34)\end{array}$ & 1.00 \\
\hline Rural* & $\begin{array}{l}0.08 \\
(0.27)\end{array}$ & $\begin{array}{l}0.92 \\
(0.27)\end{array}$ & 1.00 \\
\hline \multicolumn{4}{|c|}{ Marital Status } \\
\hline Married* & $\begin{array}{l}0.11 \\
(0.32)\end{array}$ & $\begin{array}{l}0.89 \\
(0.32)\end{array}$ & 1.00 \\
\hline Single* & $\begin{array}{l}0.20 \\
(0.40)\end{array}$ & $\begin{array}{l}0.80 \\
(0.40)\end{array}$ & 1.00 \\
\hline Widowed/Divorced* & $\begin{array}{l}0.06 \\
(0.25)\end{array}$ & $\begin{array}{l}0.94 \\
(0.25)\end{array}$ & 1.00 \\
\hline \multicolumn{4}{|c|}{ Education } \\
\hline Years of Schooling & $\begin{array}{l}9.63 \\
(4.16)\end{array}$ & $\begin{array}{l}6.14 \\
(4.33)\end{array}$ & $\begin{array}{l}6.54 \\
(4.45)\end{array}$ \\
\hline $\begin{array}{l}\text { Years of Schooling- } \\
\text { Squared }\end{array}$ & $\begin{array}{l}110.11 \\
(81.60)\end{array}$ & $\begin{array}{l}56.35 \\
(67.17)\end{array}$ & $\begin{array}{l}62.52 \\
(71.08)\end{array}$ \\
\hline Illiterate* & $\begin{array}{l}0.01 \\
(0.07)\end{array}$ & $\begin{array}{l}0.99 \\
(0.07)\end{array}$ & 1.00 \\
\hline Non-Graduate* & $\begin{array}{l}0.02 \\
(0.15)\end{array}$ & $\begin{array}{l}0.98 \\
(0.15)\end{array}$ & 1.00 \\
\hline Primary School* & $\begin{array}{l}0.08 \\
(0.28)\end{array}$ & $\begin{array}{l}0.92 \\
(0.28)\end{array}$ & 1.00 \\
\hline Middle School* & $\begin{array}{l}0.16 \\
(0.37)\end{array}$ & $\begin{array}{l}0.84 \\
(0.37)\end{array}$ & 1.00 \\
\hline High School* & $\begin{array}{l}0.18 \\
(0.39)\end{array}$ & $\begin{array}{l}0.82 \\
(0.39)\end{array}$ & 1.00 \\
\hline University ${ }^{*} *$ & $\begin{array}{l}0.27 \\
(0.45)\end{array}$ & $\begin{array}{l}0.73 \\
(0.45)\end{array}$ & 1.00 \\
\hline \multicolumn{4}{|c|}{ Labor Market Status } \\
\hline Employed* & $\begin{array}{l}0.20 \\
(0.40)\end{array}$ & $\begin{array}{l}0.80 \\
(0.40)\end{array}$ & 1.00 \\
\hline Unemployed* & $\begin{array}{l}0.20 \\
(0.40)\end{array}$ & $\begin{array}{l}0.80 \\
(0.40)\end{array}$ & 1.00 \\
\hline Out of Labor Force* & $\begin{array}{l}0.05 \\
(0.22)\end{array}$ & $\begin{array}{l}0.95 \\
(0.22)\end{array}$ & 1.00 \\
\hline $\begin{array}{l}\text { Log Household Income } \\
\text { (TL) }\end{array}$ & $\begin{array}{l}7.19 \\
(0.60)\end{array}$ & $\begin{array}{l}6.88 \\
(0.61)\end{array}$ & $\begin{array}{l}6.92 \\
(0.62)\end{array}$ \\
\hline $\begin{array}{l}\text { Number of Observations } \\
\text { in } 2008\end{array}$ & 1338 & 10439 & 11777 \\
\hline $\begin{array}{l}\text { Number of Observations } \\
\text { in } 2010\end{array}$ & 1495 & 10285 & 11780 \\
\hline $\begin{array}{l}\text { Number of Observations } \\
\text { in } 2012\end{array}$ & 2500 & 20436 & 22936 \\
\hline Total Observations & 5333 & 41160 & 46493 \\
\hline
\end{tabular}

Source: 2008,2010,2012 Turkish Health Survey

Notes : (1)*indicates a dummy variable

(2) The numbers in the paranthesis are standard deviations 
Table 2b. Marginal Effects from Probit Estimation Results for Alcohol Consumption with Years of Schooling (\%)

\begin{tabular}{|c|c|c|c|c|c|}
\hline Variable & $(1)$ & (2) & (3) & (4) & $(5)$ \\
\hline $\begin{array}{l}\text { Years of } \\
\text { Schooling }\end{array}$ & $\begin{array}{l}2.93 * * * \\
(0.14)\end{array}$ & $\begin{array}{l}2.44 * * * \\
(0.15)\end{array}$ & $\begin{array}{l}2.47 * * * \\
(0.15)\end{array}$ & $\begin{array}{l}2.57 * * * \\
(0.15)\end{array}$ & $\begin{array}{l}2.36 * * * \\
(0.15)\end{array}$ \\
\hline $\begin{array}{l}\text { Years of } \\
\text { Schooling } \\
\text { Square }\end{array}$ & $\begin{array}{l}-0.08 * * * \\
(0.008)\end{array}$ & $\begin{array}{l}-0.06 * * * \\
(0.008)\end{array}$ & $\begin{array}{l}-0.06 * * * \\
(0.008)\end{array}$ & $\begin{array}{l}-0.07 * * * \\
(0.008)\end{array}$ & $\begin{array}{l}-0.07 * * * \\
(0.008)\end{array}$ \\
\hline Male & $\begin{array}{l}12.69 * * * \\
(0.29)\end{array}$ & $\begin{array}{l}12.93 * * * \\
(0.30)\end{array}$ & $\begin{array}{l}13.24 * * * \\
(0.30)\end{array}$ & $\begin{array}{l}11.11^{* * * *} \\
(0.35)\end{array}$ & $\begin{array}{l}11.60 \text { *** } \\
(0.35)\end{array}$ \\
\hline $\operatorname{Age}\left(\mathrm{x10}^{-1}\right)$ & & $\begin{array}{l}7.58 * * * \\
(0.73)\end{array}$ & $\begin{array}{l}9.09 * * * \\
(0.75)\end{array}$ & $\begin{array}{l}8.45 * * * \\
(0.74)\end{array}$ & $\begin{array}{l}7.64 * * * \\
(0.75)\end{array}$ \\
\hline $\begin{array}{l}\text { Age } \\
\text { Square }\left(\mathbf{x 1 0}^{-3}\right)\end{array}$ & & $\begin{array}{l}-8.54 * * * \\
(0.74)\end{array}$ & $\begin{array}{l}-10.04 * * * \\
(0.76)\end{array}$ & $\begin{array}{l}-8.66 * * * \\
(0.75)\end{array}$ & $\begin{array}{l}-8.07 * * * \\
(0.76)\end{array}$ \\
\hline Urban & & $\begin{array}{l}1.11 * * * \\
(0.33)\end{array}$ & $\begin{array}{l}1.07 * * * \\
(0.33)\end{array}$ & $\begin{array}{l}1.41 * * * \\
(0.33)\end{array}$ & $\begin{array}{l}0.40 \\
(0.34)\end{array}$ \\
\hline \multicolumn{6}{|c|}{ Marital Status } \\
\hline Married & & & $\begin{array}{l}-4.63 * * * \\
(0.56)\end{array}$ & $\begin{array}{l}-4.20 * * * \\
(0.56)\end{array}$ & $\begin{array}{l}-4.75 * * * \\
(0.57)\end{array}$ \\
\hline Single & & & $\begin{array}{l}-1.70 * * * \\
(0.72)\end{array}$ & $\begin{array}{l}-1.40 * * \\
(0.72)\end{array}$ & $\begin{array}{l}-2.10 * * * \\
(0.73)\end{array}$ \\
\hline \multicolumn{6}{|c|}{ Labor Force Status } \\
\hline Employed & & & & $\begin{array}{l}4.37 * * * \\
(0.36)\end{array}$ & $\begin{array}{l}3.96 * * * \\
(0.37)\end{array}$ \\
\hline Unemployed & & & & $\begin{array}{l}4.74 * * * \\
(0.73)\end{array}$ & $\begin{array}{l}5.92 * * * \\
(0.75)\end{array}$ \\
\hline $\begin{array}{l}\text { Log } \\
\text { Household } \\
\text { Income }\end{array}$ & & & & & $\begin{array}{l}3.91 * * * \\
(0.28)\end{array}$ \\
\hline Dummy10 & $\begin{array}{l}1.22^{* * * *} \\
(0.38)\end{array}$ & $\begin{array}{l}1.30 * * * \\
(0.38)\end{array}$ & $\begin{array}{l}1.26 * * * \\
(0.38)\end{array}$ & $\begin{array}{l}1.23 * * * \\
(0.38)\end{array}$ & $\begin{array}{l}0.64 * \\
(0.38)\end{array}$ \\
\hline Dummy12 & $\begin{array}{l}-1.42 * * * \\
(0.33)\end{array}$ & $\begin{array}{l}-1.37 * * * \\
(0.33)\end{array}$ & $\begin{array}{l}-1.44 * * * \\
(0.33)\end{array}$ & $\begin{array}{l}-1.50 * * * \\
(0.33)\end{array}$ & $\begin{array}{l}-2.76 * * * \\
(0.35)\end{array}$ \\
\hline Pseudo R2 & 0.15 & 0.16 & 0.16 & 0.17 & 0.17 \\
\hline $\begin{array}{l}\text { (-) Log- } \\
\text { Likelihood }\end{array}$ & 13984 & 13883 & 13836 & 13761 & 13537 \\
\hline $\mathbf{N}$ & 46493 & 46493 & 46493 & 46493 & 46024 \\
\hline
\end{tabular}

Source:Authors' computations using 2008-2010-2012 Turkish Health Survey

Notes:

(1)*** indicates $1 \%$ level of significance, $* *$ indicates $5 \%$ level of significance, $*_{\text {indicates }} 10 \%$ level of significance.

(2) Robust standard errors are shown in paranthesis.

(3) Marginal effects are computed at the means of the variables 
Table 2c. Marginal Effects from Probit Estimation Results for Alcohol Consumption with Education Levels (\%)

\begin{tabular}{|c|c|c|c|c|c|}
\hline Variable & $(1)$ & $(2)$ & (3) & $(4)$ & $(5)$ \\
\hline \multicolumn{6}{|c|}{ Education } \\
\hline Non-Graduate & $\begin{array}{l}5.85 * * * \\
(1.37)\end{array}$ & $\begin{array}{l}5.58 * * * \\
(1.36)\end{array}$ & $\begin{array}{l}5.91 * * * \\
(1.35)\end{array}$ & $\begin{array}{l}5.98 * * * \\
(1.35)\end{array}$ & $\begin{array}{l}5.64 * * * \\
(1.35)\end{array}$ \\
\hline $\begin{array}{l}\text { Primary } \\
\text { School }\end{array}$ & $\begin{array}{l}15.57 * * * \\
(1.05)\end{array}$ & $\begin{array}{l}13.31 * * * \\
(1.06)\end{array}$ & $\begin{array}{l}13.78 * * * \\
(1.06)\end{array}$ & $\begin{array}{l}13.82 * * * \\
(1.06)\end{array}$ & $\begin{array}{l}12.59 * * * \\
(1.06)\end{array}$ \\
\hline Middle School & $\begin{array}{l}21.23 * * * \\
(1.11)\end{array}$ & $\begin{array}{l}18.62^{* * * *} \\
(1.13)\end{array}$ & $\begin{array}{l}18.92 * * * \\
(1.13)\end{array}$ & $\begin{array}{l}18.91 * * * \\
(1.13)\end{array}$ & $\begin{array}{l}16.91 * * * \\
(1.14)\end{array}$ \\
\hline High School & $\begin{array}{l}23.25 * * * \\
(1.08)\end{array}$ & $\begin{array}{l}20.46 * * * \\
(1.11)\end{array}$ & $\begin{array}{l}20.72 * * * \\
(1.11)\end{array}$ & $\begin{array}{l}20.62 * * * \\
(1.11)\end{array}$ & $\begin{array}{l}17.95 * * * \\
(1.12)\end{array}$ \\
\hline University+ & $\begin{array}{l}28.21 * * * \\
(1.08)\end{array}$ & $\begin{array}{l}25.43 * * * \\
(1.11)\end{array}$ & $\begin{array}{l}25.60 * * * \\
(1.11)\end{array}$ & $\begin{array}{l}24.83 * * * \\
(1.11)\end{array}$ & $\begin{array}{l}20.91 * * \\
(1.14)\end{array}$ \\
\hline Male & $\begin{array}{l}12.59 * * * \\
(0.29)\end{array}$ & $\begin{array}{l}12.84 * * * \\
(0.30)\end{array}$ & $\begin{array}{l}13.16 * * * \\
(0.30)\end{array}$ & $\begin{array}{l}11.06 * * * \\
(0.35)\end{array}$ & $\begin{array}{l}11.56 * * * \\
(0.35)\end{array}$ \\
\hline $\operatorname{Age}\left(\mathrm{x10}^{-1}\right)$ & & $\begin{array}{l}7.31 * * * \\
(0.73)\end{array}$ & $\begin{array}{l}8.80 * * * \\
(0.76)\end{array}$ & $\begin{array}{l}8.18 * * * \\
(0.75)\end{array}$ & $\begin{array}{l}7.38 * * * \\
(0.75)\end{array}$ \\
\hline $\begin{array}{l}\text { Age } \\
\text { Square }\left(\times 10^{-3}\right)\end{array}$ & & $\begin{array}{l}-8.24 * * * \\
(0.75)\end{array}$ & $\begin{array}{l}-9.74 * * * \\
(0.77)\end{array}$ & $\begin{array}{l}-8.38 * * * \\
(0.76)\end{array}$ & $\begin{array}{l}-7.82 * * * \\
(0.76)\end{array}$ \\
\hline Urban & & $\begin{array}{l}1.15 * * * \\
(0.33)\end{array}$ & $\begin{array}{l}1.12 * * * \\
(0.33)\end{array}$ & $\begin{array}{l}1.44 * * * \\
(0.33)\end{array}$ & $\begin{array}{l}0.44 \\
(0.34)\end{array}$ \\
\hline \multicolumn{6}{|c|}{ Marital Status } \\
\hline Married & & & $\begin{array}{l}-4.78 * * * \\
(0.57)\end{array}$ & $\begin{array}{l}-4.35 * * * \\
(0.57)\end{array}$ & $\begin{array}{l}-4.90 * * * \\
(0.57)\end{array}$ \\
\hline Single & & & $\begin{array}{l}-1.80 * * * \\
(0.73)\end{array}$ & $\begin{array}{l}-1.51 * * * \\
(0.72)\end{array}$ & $\begin{array}{l}-2.21 * * * \\
(0.73)\end{array}$ \\
\hline \multicolumn{6}{|c|}{ Labor Force Status } \\
\hline Employed & & & & $\begin{array}{l}4.30 * * * \\
(0.36)\end{array}$ & $\begin{array}{l}3.89 * * * \\
(0.37)\end{array}$ \\
\hline Unemployed & & & & $\begin{array}{l}4.67 * * * \\
(0.73)\end{array}$ & $\begin{array}{l}5.85 * * * \\
(0.75)\end{array}$ \\
\hline $\begin{array}{l}\text { Log } \\
\text { Household } \\
\text { Income }\end{array}$ & & & & & $\begin{array}{l}3.90 * * * \\
(0.28)\end{array}$ \\
\hline Dummy10 & $\begin{array}{l}1.22 * * * \\
(0.38)\end{array}$ & $\begin{array}{l}1.30 * * * \\
(0.38)\end{array}$ & $\begin{array}{l}1.25 * * * \\
(0.38)\end{array}$ & $\begin{array}{l}1.22 * * * \\
(0.38)\end{array}$ & $\begin{array}{l}0.63 * \\
(0.38)\end{array}$ \\
\hline Dummy12 & $\begin{array}{l}-1.44 * * * \\
(0.33)\end{array}$ & $\begin{array}{l}-1.39 * * * \\
(0.33)\end{array}$ & $\begin{array}{l}-1.46^{* * * *} \\
(0.33)\end{array}$ & $\begin{array}{l}-1.52 * * * \\
(0.33)\end{array}$ & $\begin{array}{l}-2.77 * * * \\
(0.35)\end{array}$ \\
\hline Pseudo R2 & 0.16 & 0.16 & 0.17 & 0.17 & 0.18 \\
\hline $\begin{array}{l}\text { (-) Log- } \\
\text { Likelihood }\end{array}$ & 13961 & 13867 & 13818 & 13746 & 13523 \\
\hline $\mathbf{N}$ & 46493 & 46493 & 46493 & 46493 & 46024 \\
\hline
\end{tabular}

Source:Authors' computations using 2008-2010-2012 Turkish Health Survey

Notes:

(1)*** indicates $1 \%$ level of significance, $* *$ indicates $5 \%$ level of significance, $*$ indicates $10 \%$ level of significance.

(2) Robust standard errors are shown in paranthesis.

(3) Marginal effects are computed at the means of the variables 
Table 3a. Descriptive Statistics for Fruit and Vegetables (FV) Consumption

\begin{tabular}{|c|c|c|c|}
\hline Variable & $\begin{array}{l}\text { Consume FV } \\
\text { Regularly } \\
\end{array}$ & Not Consume FV & Total \\
\hline Male* & $\begin{array}{l}0.59 \\
(0.49)\end{array}$ & $\begin{array}{l}0.41 \\
(0.49)\end{array}$ & 1.00 \\
\hline Female* & $\begin{array}{l}0.57 \\
(0.49)\end{array}$ & $\begin{array}{l}0.43 \\
(0.49)\end{array}$ & 1.00 \\
\hline Age (Years) & $\begin{array}{l}46.72 \\
(14.68)\end{array}$ & $\begin{array}{l}48.34 \\
(14.93)\end{array}$ & $\begin{array}{l}47.40 \\
(14.81)\end{array}$ \\
\hline Age-Squared & $\begin{array}{l}2398 \\
(1516)\end{array}$ & $\begin{array}{l}2559 \\
(1571)\end{array}$ & $\begin{array}{l}2466 \\
(1541)\end{array}$ \\
\hline Urban* & $\begin{array}{l}0.60 \\
(0.49)\end{array}$ & $\begin{array}{l}0.40 \\
(0.49)\end{array}$ & 1.00 \\
\hline Rural* & $\begin{array}{l}0.54 \\
(0.50)\end{array}$ & $\begin{array}{l}0.46 \\
(0.50)\end{array}$ & 1.00 \\
\hline \multicolumn{4}{|c|}{ Marital Status } \\
\hline Married* & $\begin{array}{l}0.58 \\
(0.49)\end{array}$ & $\begin{array}{l}0.42 \\
(0.49)\end{array}$ & 1.00 \\
\hline Single* & $\begin{array}{l}0.65 \\
(0.48)\end{array}$ & $\begin{array}{l}0.35 \\
(0.48)\end{array}$ & 1.00 \\
\hline Widowed/Divorced* & $\begin{array}{l}0.54 \\
(0.50)\end{array}$ & $\begin{array}{l}0.46 \\
(0.50)\end{array}$ & 1.00 \\
\hline \multicolumn{4}{|c|}{ Education } \\
\hline Years of Schooling & $\begin{array}{l}6.85 \\
(4.46)\end{array}$ & $\begin{array}{l}6.11 \\
(4.39)\end{array}$ & $\begin{array}{l}6.54 \\
(4.45)\end{array}$ \\
\hline $\begin{array}{l}\text { Years of Schooling- } \\
\text { Squared }\end{array}$ & $\begin{array}{l}66.80 \\
(72.81)\end{array}$ & $\begin{array}{l}56.68 \\
(68.19)\end{array}$ & $\begin{array}{l}62.55 \\
(71.08)\end{array}$ \\
\hline Illiterate* & $\begin{array}{l}0.50 \\
(0.50)\end{array}$ & $\begin{array}{l}0.50 \\
(0.50)\end{array}$ & 1.00 \\
\hline Non-Graduate* & $\begin{array}{l}0.54 \\
(0.50)\end{array}$ & $\begin{array}{l}0.46 \\
(0.50)\end{array}$ & 1.00 \\
\hline Primary School* & $\begin{array}{l}0.57 \\
(0.50)\end{array}$ & $\begin{array}{l}0.43 \\
(0.50)\end{array}$ & 1.00 \\
\hline Middle School* & $\begin{array}{l}0.60 \\
(0.49)\end{array}$ & $\begin{array}{l}0.40 \\
(0.49)\end{array}$ & 1.00 \\
\hline High School* & $\begin{array}{l}0.62 \\
(0.48)\end{array}$ & $\begin{array}{l}0.38 \\
(0.48)\end{array}$ & 1.00 \\
\hline University+* & $\begin{array}{l}0.64 \\
(0.48)\end{array}$ & $\begin{array}{l}0.36 \\
(0.48)\end{array}$ & 1.00 \\
\hline \multicolumn{4}{|c|}{ Labor Market Status } \\
\hline Employed* & $\begin{array}{l}0.59 \\
(0.49)\end{array}$ & $\begin{array}{l}0.41 \\
(0.49)\end{array}$ & 1.00 \\
\hline Unemployed* & $\begin{array}{l}0.57 \\
(0.49)\end{array}$ & $\begin{array}{l}0.43 \\
(0.49)\end{array}$ & 1.00 \\
\hline Out of Labor Force* & $\begin{array}{l}0.57 \\
(0.49)\end{array}$ & $\begin{array}{l}0.43 \\
(0.49)\end{array}$ & 1.00 \\
\hline $\begin{array}{l}\text { Log Household Income } \\
\text { (TL) }\end{array}$ & $\begin{array}{l}6.93 \\
(0.61)\end{array}$ & $\begin{array}{l}6.89 \\
(0.62)\end{array}$ & $\begin{array}{l}6.92 \\
(0.62)\end{array}$ \\
\hline $\begin{array}{l}\text { Number of Observations } \\
\text { in } 2008\end{array}$ & 9665 & 2089 & 11754 \\
\hline $\begin{array}{l}\text { Number of Observations } \\
\text { in } 2010\end{array}$ & 6074 & 5696 & 11770 \\
\hline $\begin{array}{l}\text { Number of Observations } \\
\text { in } 2012\end{array}$ & 11199 & 11731 & 22930 \\
\hline Total Observations & 26938 & 19516 & 46454 \\
\hline
\end{tabular}

Source: 2008,2010,2012 Turkish Health Survey

Notes : (1)*indicates a dummy variable

(2) The numbers in the paranthesis are standard deviations 
Table 3b. Marginal Effects from Probit Estimation Results for Fruit and Vegetable Consumption with Years of Schooling (\%)

\begin{tabular}{|c|c|c|c|c|c|}
\hline Variable & $(1)$ & (2) & (3) & (4) & $(5)$ \\
\hline $\begin{array}{l}\text { Years of } \\
\text { Schooling }\end{array}$ & $\begin{array}{l}1.87 * * * \\
(0.16)\end{array}$ & $\begin{array}{l}1.76^{* * * *} \\
(0.17)\end{array}$ & $\begin{array}{l}1.77 * * * \\
(0.17)\end{array}$ & $\begin{array}{l}1.74 * * * \\
(0.17)\end{array}$ & $\begin{array}{l}1.42 * * * \\
(0.17)\end{array}$ \\
\hline $\begin{array}{l}\text { Years of } \\
\text { Schooling } \\
\text { Square }\end{array}$ & $\begin{array}{l}-0.05 * * * \\
(0.01)\end{array}$ & $\begin{array}{l}-0.05 * * * \\
(0.01)\end{array}$ & $\begin{array}{l}-0.05 * * * \\
(0.01)\end{array}$ & $\begin{array}{l}-0.05 * * * \\
(0.01)\end{array}$ & $\begin{array}{l}-0.05 * * * \\
(0.01)\end{array}$ \\
\hline Male & $\begin{array}{l}-0.16 \\
(0.45)\end{array}$ & $\begin{array}{l}0.11 \\
(0.46)\end{array}$ & $\begin{array}{l}-0.09 \\
(0.47)\end{array}$ & $\begin{array}{l}1.25^{* *} \\
(0.54)\end{array}$ & $\begin{array}{l}1.94 * * * \\
(0.55)\end{array}$ \\
\hline $\operatorname{Age}\left(x_{10}^{-1}\right)$ & & $\begin{array}{l}-3.02 * * * \\
(1.01)\end{array}$ & $\begin{array}{l}-2.19 * * \\
(1.04)\end{array}$ & $\begin{array}{l}-2.04 * * \\
(1.04)\end{array}$ & $\begin{array}{l}-3.34 * * * \\
(1.05)\end{array}$ \\
\hline $\begin{array}{l}\text { Age } \\
\text { Square }\left(\times_{10}^{-3}\right)\end{array}$ & & $\begin{array}{l}3.02 * * * \\
(0.97)\end{array}$ & $\begin{array}{l}2.44 * * \\
(1.00)\end{array}$ & $\begin{array}{l}1.99 * * \\
(1.01)\end{array}$ & $\begin{array}{l}3.02 * * * \\
(1.01)\end{array}$ \\
\hline Urban & & $\begin{array}{l}4.64 * * * \\
(0.50)\end{array}$ & $\begin{array}{l}4.71 * * * \\
(0.50)\end{array}$ & $\begin{array}{l}4.47 * * * \\
(0.50)\end{array}$ & $\begin{array}{l}3.01 * * * \\
(0.51)\end{array}$ \\
\hline \multicolumn{6}{|c|}{ Marital Status } \\
\hline Married & & & $\begin{array}{l}1.01 \\
(0.78)\end{array}$ & $\begin{array}{l}0.63 \\
(0.79)\end{array}$ & $\begin{array}{l}-0.21 \\
(0.79)\end{array}$ \\
\hline Single & & & $\begin{array}{l}4.89 * * * \\
(1.16)\end{array}$ & $\begin{array}{l}5.03 * * * \\
(1.16)\end{array}$ & $\begin{array}{l}4.09 * * * \\
(1.17)\end{array}$ \\
\hline \multicolumn{6}{|c|}{ Labor Force Status } \\
\hline Employed & & & & $\begin{array}{l}-2.42 * * * \\
(0.57)\end{array}$ & $\begin{array}{l}-3.01 * * * \\
(0.58)\end{array}$ \\
\hline Unemployed & & & & $\begin{array}{l}-6.33 * * * \\
(1.36)\end{array}$ & $\begin{array}{l}-4.52 * * * \\
(1.38)\end{array}$ \\
\hline $\begin{array}{l}\text { Log } \\
\text { Household } \\
\text { Income }\end{array}$ & & & & & $\begin{array}{l}5.85^{* * * *} \\
(0.44)\end{array}$ \\
\hline Dummy10 & $\begin{array}{l}-32.25 * * * \\
(0.59)\end{array}$ & $\begin{array}{l}-32.30 * * * \\
(0.59)\end{array}$ & $\begin{array}{l}-32.30 * * * \\
(0.59)\end{array}$ & $\begin{array}{l}-32.28 * * * \\
(0.59)\end{array}$ & $\begin{array}{l}-33.13 * * * \\
(0.59)\end{array}$ \\
\hline Dummy12 & $\begin{array}{l}-35.23 * * * \\
(0.51)\end{array}$ & $\begin{array}{l}-35.34 * * * \\
(0.51)\end{array}$ & $\begin{array}{l}-35.35 * * * \\
(0.51)\end{array}$ & $\begin{array}{l}-35.38 * * * \\
(0.50)\end{array}$ & $\begin{array}{l}-37.29 * * * \\
(0.52)\end{array}$ \\
\hline Pseudo R2 & 0.07 & 0.07 & 0.07 & 0.08 & 0.08 \\
\hline $\begin{array}{l}\text { (-) Log- } \\
\text { Likelihood }\end{array}$ & 29298 & 29251 & 29240 & 29225 & 28854 \\
\hline $\mathbf{N}$ & 46454 & 46454 & 46454 & 46454 & 45990 \\
\hline
\end{tabular}

Source:Authors' computations using 2008-2010-2012 Turkish Health Survey

Notes:

$(1)^{* * *}$ indicates $1 \%$ level of significance, $* *$ indicates $5 \%$ level of significance, *indicates $10 \%$ level of significance.

(2) Robust standard errors are shown in paranthesis.

(3) Marginal effects are computed at the means of the variables 
Table 3c. Marginal Effects from Probit Estimation Results for Fruit and Vegetable Consumption with Education Levels (\%)

\begin{tabular}{|c|c|c|c|c|c|}
\hline Variable & $(1)$ & $(2)$ & $(3)$ & $(4)$ & $(5)$ \\
\hline \multicolumn{6}{|c|}{ Education } \\
\hline Non-Graduate & $\begin{array}{l}4.53 * * * \\
(1.05)\end{array}$ & $\begin{array}{l}4.27 * * * \\
(1.05)\end{array}$ & $\begin{array}{l}4.22 * * * \\
(1.05)\end{array}$ & $\begin{array}{l}4.11 * * * \\
(1.05)\end{array}$ & $\begin{array}{l}3.58 * * * \\
(1.06)\end{array}$ \\
\hline $\begin{array}{l}\text { Primary } \\
\text { School }\end{array}$ & $\begin{array}{l}8.12 * * * \\
(0.68)\end{array}$ & $\begin{array}{l}7.75 * * * \\
(0.73)\end{array}$ & $\begin{array}{l}7.78 * * * \\
(0.74)\end{array}$ & $\begin{array}{l}7.73 * * * \\
(0.73)\end{array}$ & $\begin{array}{l}5.95 * * * \\
(0.75)\end{array}$ \\
\hline Middle School & $\begin{array}{l}12.21 * * * \\
(0.95)\end{array}$ & $\begin{array}{l}11.06 * * * \\
(1.02)\end{array}$ & $\begin{array}{l}10.96 * * * \\
(1.02)\end{array}$ & $\begin{array}{l}10.97 * * * \\
(1.02)\end{array}$ & $\begin{array}{l}8.12 * * * \\
(1.04)\end{array}$ \\
\hline High School & $\begin{array}{l}14.02 * * * \\
(0.83)\end{array}$ & $\begin{array}{l}12.56 * * * \\
(0.92)\end{array}$ & $\begin{array}{l}12.35 * * * \\
(0.92)\end{array}$ & $\begin{array}{l}12.45 * * * \\
(0.92)\end{array}$ & $\begin{array}{l}8.56 * * * \\
(0.97)\end{array}$ \\
\hline University+ & $\begin{array}{l}16.27 * * * \\
(0.88)\end{array}$ & $\begin{array}{l}14.58 * * * \\
(0.97)\end{array}$ & $\begin{array}{l}14.12 * * * \\
(0.98)\end{array}$ & $\begin{array}{l}14.63 * * * \\
(0.99)\end{array}$ & $\begin{array}{l}8.81 * * * \\
(1.08)\end{array}$ \\
\hline Male & $\begin{array}{l}-0.18 \\
(0.45)\end{array}$ & $\begin{array}{l}0.08 \\
(0.46)\end{array}$ & $\begin{array}{l}-0.11 \\
(0.47)\end{array}$ & $\begin{array}{l}1.23 * * \\
(0.54)\end{array}$ & $\begin{array}{l}1.92 * * * \\
(0.55)\end{array}$ \\
\hline $\operatorname{Age}\left(\times 10^{-1}\right)$ & & $\begin{array}{l}-3.07 * * * \\
(1.02)\end{array}$ & $\begin{array}{l}-2.24 * * * \\
(1.05)\end{array}$ & $\begin{array}{l}-2.11 * * \\
(1.05)\end{array}$ & $\begin{array}{l}-3.37 * * * \\
(1.06)\end{array}$ \\
\hline $\begin{array}{l}\text { Age } \\
\operatorname{Square}\left(\times 10^{-3}\right)\end{array}$ & & $\begin{array}{l}3.07 * * * \\
(0.98)\end{array}$ & $\begin{array}{l}2.49 * * * \\
(1.01)\end{array}$ & $\begin{array}{l}2.04 * * \\
(1.01)\end{array}$ & $\begin{array}{l}3.05 * * * \\
(1.02)\end{array}$ \\
\hline Urban & & $\begin{array}{l}4.65 * * * \\
(0.49)\end{array}$ & $\begin{array}{l}4.72 * * * \\
(0.50)\end{array}$ & $\begin{array}{l}4.48 * * * \\
(0.50)\end{array}$ & $\begin{array}{l}3.02 * * * \\
(0.52)\end{array}$ \\
\hline \multicolumn{6}{|c|}{ Marital Status } \\
\hline Married & & & $\begin{array}{l}0.98 \\
(0.78)\end{array}$ & $\begin{array}{l}0.58 \\
(0.79)\end{array}$ & $\begin{array}{l}-0.24 \\
(0.79)\end{array}$ \\
\hline Single & & & $\begin{array}{l}4.86 * * * \\
(1.16)\end{array}$ & $\begin{array}{l}5.00 * * * \\
(1.16)\end{array}$ & $\begin{array}{l}4.06 * * * \\
(1.17)\end{array}$ \\
\hline \multicolumn{6}{|c|}{ Labor Force Status } \\
\hline Employed & & & & $\begin{array}{l}-2.44 * * * \\
(0.57)\end{array}$ & $\begin{array}{l}-3.02 * * * \\
(0.58)\end{array}$ \\
\hline Unemployed & & & & $\begin{array}{l}-6.33 * * * \\
(1.36)\end{array}$ & $\begin{array}{l}-4.51 * * * \\
(1.38)\end{array}$ \\
\hline $\begin{array}{l}\text { Log Household } \\
\text { Income }\end{array}$ & & & & & $\begin{array}{l}5.85 * * * \\
(0.44)\end{array}$ \\
\hline Dummy10 & $\begin{array}{l}-32.26 * * * \\
(0.59)\end{array}$ & $\begin{array}{l}-32.32 * * * \\
(0.59)\end{array}$ & $\begin{array}{l}-32.32 * * * \\
(0.59)\end{array}$ & $\begin{array}{l}-32.30 * * * \\
(0.59)\end{array}$ & $\begin{array}{l}-33.15 * * * \\
(0.59)\end{array}$ \\
\hline Dummy12 & $\begin{array}{l}-35.24 * * * \\
(0.51)\end{array}$ & $\begin{array}{l}-35.35 * * * \\
(0.51)\end{array}$ & $\begin{array}{l}-35.36 * * * \\
(0.51)\end{array}$ & $\begin{array}{l}-35.39 * * * \\
(0.51)\end{array}$ & $\begin{array}{l}-37.30 * * * \\
(0.53)\end{array}$ \\
\hline Pseudo R2 & 0.07 & 0.07 & 0.07 & 0.08 & 0.08 \\
\hline $\begin{array}{l}\text { (-) Log- } \\
\text { Likelihood }\end{array}$ & 29297 & 29250 & 29239 & 29224 & 28853 \\
\hline $\mathbf{N}$ & 46454 & 46454 & 46454 & 46454 & 45990 \\
\hline
\end{tabular}

Source:Authors' computations using 2008-2010-2012 Turkish Health Survey

Notes:

$(1)^{* * *}$ indicates $1 \%$ level of significance, $* *$ indicates $5 \%$ level of significance, *indicates $10 \%$ level of significance.

(2) Robust standard errors are shown in paranthesis.

(3) Marginal effects are computed at the means of the variables 
Table 4a. Descriptive Statistics for Exercise

\begin{tabular}{|c|c|c|c|}
\hline Variable & Exercise Regularly & $\begin{array}{l}\text { Not Exercise } \\
\text { Regularly } \\
\end{array}$ & Total \\
\hline Male* & $\begin{array}{l}0.71 \\
(0.45)\end{array}$ & $\begin{array}{l}0.29 \\
(0.45)\end{array}$ & 1.00 \\
\hline Female* & $\begin{array}{l}0.63 \\
(0.48)\end{array}$ & $\begin{array}{l}0.37 \\
(0.48)\end{array}$ & 1.00 \\
\hline Age (Years) & $\begin{array}{l}46.21 \\
(13.84)\end{array}$ & $\begin{array}{l}50.07 \\
(16.33)\end{array}$ & $\begin{array}{l}47.50 \\
(14.83)\end{array}$ \\
\hline Age-Squared & $\begin{array}{l}2326 \\
(1405)\end{array}$ & $\begin{array}{l}2774 \\
(1757)\end{array}$ & $\begin{array}{l}2475 \\
(1546)\end{array}$ \\
\hline Urban* & $\begin{array}{l}0.67 \\
(0.47)\end{array}$ & $\begin{array}{l}0.33 \\
(0.47)\end{array}$ & 1.00 \\
\hline Rural* & $\begin{array}{l}0.66 \\
(0.47)\end{array}$ & $\begin{array}{l}0.34 \\
(0.47)\end{array}$ & 1.00 \\
\hline \multicolumn{4}{|c|}{ Marital Status } \\
\hline Married* & $\begin{array}{l}0.68 \\
(0.47)\end{array}$ & $\begin{array}{l}0.32 \\
(0.47)\end{array}$ & 1.00 \\
\hline Single* & $\begin{array}{l}0.69 \\
(0.46)\end{array}$ & $\begin{array}{l}0.31 \\
(0.46)\end{array}$ & 1.00 \\
\hline Widowed/Divorced* & $\begin{array}{l}0.54 \\
(0.50)\end{array}$ & $\begin{array}{l}0.46 \\
(0.50)\end{array}$ & 1.00 \\
\hline \multicolumn{4}{|c|}{ Education } \\
\hline Years of Schooling & $\begin{array}{l}7.00 \\
(4.36)\end{array}$ & $\begin{array}{l}5.78 \\
(4.48)\end{array}$ & $\begin{array}{l}6.60 \\
(4.44)\end{array}$ \\
\hline $\begin{array}{l}\text { Years of Schooling- } \\
\text { Squared }\end{array}$ & $\begin{array}{l}68.18 \\
(72.66)\end{array}$ & $\begin{array}{l}53.56 \\
(67.69)\end{array}$ & $\begin{array}{l}63.31 \\
(71.37)\end{array}$ \\
\hline Illiterate* & $\begin{array}{l}0.48 \\
(0.50)\end{array}$ & $\begin{array}{l}0.52 \\
(0.50)\end{array}$ & 1.00 \\
\hline Non-Graduate* & $\begin{array}{l}0.61 \\
(0.49)\end{array}$ & $\begin{array}{l}0.39 \\
(0.49)\end{array}$ & 1.00 \\
\hline Primary School* & $\begin{array}{l}0.68 \\
(0.46)\end{array}$ & $\begin{array}{l}0.32 \\
(0.46)\end{array}$ & 1.00 \\
\hline Middle School* & $\begin{array}{l}0.72 \\
(0.45)\end{array}$ & $\begin{array}{l}0.28 \\
(0.45)\end{array}$ & 1.00 \\
\hline High School* & $\begin{array}{l}0.72 \\
(0.45)\end{array}$ & $\begin{array}{l}0.28 \\
(0.45)\end{array}$ & 1.00 \\
\hline University+* & $\begin{array}{l}0.73 \\
(0.44)\end{array}$ & $\begin{array}{l}0.27 \\
(0.44)\end{array}$ & 1.00 \\
\hline \multicolumn{4}{|c|}{ Labor Market Status } \\
\hline Employed* & $\begin{array}{l}0.73 \\
(0.44)\end{array}$ & $\begin{array}{l}0.27 \\
(0.44)\end{array}$ & 1.00 \\
\hline Unemployed* & $\begin{array}{l}0.69 \\
(0.46)\end{array}$ & $\begin{array}{l}0.31 \\
(0.46)\end{array}$ & 1.00 \\
\hline Out of Labor Force* & $\begin{array}{l}0.62 \\
(0.49)\end{array}$ & $\begin{array}{l}0.38 \\
(0.49)\end{array}$ & 1.00 \\
\hline $\begin{array}{l}\text { Log Household Income } \\
\text { (TL) }\end{array}$ & $\begin{array}{l}6.95 \\
(0.61)\end{array}$ & $\begin{array}{l}6.87 \\
(0.62)\end{array}$ & $\begin{array}{l}6.93 \\
(0.61)\end{array}$ \\
\hline $\begin{array}{l}\text { Number of Observations } \\
\text { in } 2008\end{array}$ & 7029 & 4078 & 11107 \\
\hline $\begin{array}{l}\text { Number of Observations } \\
\text { in } 2010\end{array}$ & 7673 & 3118 & 10791 \\
\hline $\begin{array}{l}\text { Number of Observations } \\
\text { in } 2012\end{array}$ & 14366 & 7341 & 21707 \\
\hline Total Observations & 29068 & 14537 & 43605 \\
\hline
\end{tabular}

Source: 2008,2010,2012 Turkish Health Survey

Notes : (1)*indicates a dummy variable

(2) The numbers in the paranthesis are standard deviations 
Table 4b. Marginal Effects from Probit Estimation Results for Exercise with Years of Schooling (\%)

\begin{tabular}{|c|c|c|c|c|c|}
\hline Variable & (1) & (2) & (3) & (4) & $(5)$ \\
\hline $\begin{array}{l}\text { Years of } \\
\text { Schooling }\end{array}$ & $\begin{array}{l}3.82 * * * \\
(0.16)\end{array}$ & $\begin{array}{l}2.64 * * * \\
(0.17)\end{array}$ & $\begin{array}{l}2.60 * * * \\
(0.17)\end{array}$ & $\begin{array}{l}2.66 * * * \\
(0.17)\end{array}$ & $\begin{array}{l}2.65 * * * \\
(0.18)\end{array}$ \\
\hline $\begin{array}{l}\text { Years of } \\
\text { Schooling } \\
\text { Square }\end{array}$ & $\begin{array}{l}-0.17 * * * \\
(0.01)\end{array}$ & $\begin{array}{l}-0.11 * * * \\
(0.01)\end{array}$ & $\begin{array}{l}-0.10 * * * \\
(0.01)\end{array}$ & $\begin{array}{l}-0.11 * * * \\
(0.01)\end{array}$ & $\begin{array}{l}-0.11 * * * \\
(0.01)\end{array}$ \\
\hline Male & $\begin{array}{l}4.67 * * * \\
(0.46)\end{array}$ & $\begin{array}{l}5.43 * * * \\
(0.46)\end{array}$ & $\begin{array}{l}5.27 * * * \\
(0.47)\end{array}$ & $\begin{array}{l}3.46 * * * \\
(0.55)\end{array}$ & $\begin{array}{l}3.53 * * * \\
(0.55)\end{array}$ \\
\hline $\operatorname{Age}\left(\mathrm{x10}^{-1}\right)$ & & $\begin{array}{l}16.07 * * * \\
(1.00)\end{array}$ & $\begin{array}{l}15.22 * * * \\
(1.04)\end{array}$ & $\begin{array}{l}14.97 * * * \\
(1.04)\end{array}$ & $\begin{array}{l}14.83 * * * \\
(1.05)\end{array}$ \\
\hline $\begin{array}{l}\text { Age } \\
\text { Square }\left(\times 10^{-3}\right)\end{array}$ & & $\begin{array}{l}-18.01 \text { *** } \\
(0.96)\end{array}$ & $\begin{array}{l}-17.15^{* * *} \\
(0.99)\end{array}$ & $\begin{array}{l}-16.49 * * * \\
(1.00)\end{array}$ & $\begin{array}{l}-16.37 * * * \\
(1.00)\end{array}$ \\
\hline Urban & & $\begin{array}{l}-4.44 * * * \\
(0.51)\end{array}$ & $\begin{array}{l}-4.44 * * * \\
(0.51)\end{array}$ & $\begin{array}{l}-3.94 * * * \\
(0.51)\end{array}$ & $\begin{array}{l}-3.82 * * * \\
(0.53)\end{array}$ \\
\hline \multicolumn{6}{|c|}{ Marital Status } \\
\hline Married & & & $\begin{array}{l}1.94 * * \\
(0.78)\end{array}$ & $\begin{array}{l}2.29 * * * \\
(0.78)\end{array}$ & $\begin{array}{l}2.10^{* * * *} \\
(0.78)\end{array}$ \\
\hline Single & & & $\begin{array}{l}-0.29 \\
(1.14)\end{array}$ & $\begin{array}{l}0.12 \\
(1.15)\end{array}$ & $\begin{array}{l}-0.09 \\
(1.15)\end{array}$ \\
\hline \multicolumn{6}{|c|}{ Labor Force Status } \\
\hline Employed & & & & $\begin{array}{l}4.06 * * * \\
(0.58)\end{array}$ & $\begin{array}{l}4.11 \text { *** } \\
(0.58)\end{array}$ \\
\hline Unemployed & & & & $\begin{array}{l}0.37 \\
(1.37)\end{array}$ & $\begin{array}{l}0.18 \\
(1.39)\end{array}$ \\
\hline $\begin{array}{l}\text { Log } \\
\text { Household } \\
\text { Income }\end{array}$ & & & & & $\begin{array}{l}0.21 \\
(0.45)\end{array}$ \\
\hline Dummy10 & $\begin{array}{l}7.78 * * * \\
(0.62)\end{array}$ & $\begin{array}{l}8.24 * * * \\
(0.62)\end{array}$ & $\begin{array}{l}8.26 * * * \\
(0.62)\end{array}$ & $\begin{array}{l}8.23 * * * \\
(0.62)\end{array}$ & $\begin{array}{l}8.22 * * * \\
(0.62)\end{array}$ \\
\hline Dummy12 & $\begin{array}{l}2.13 * * * \\
(0.53)\end{array}$ & $\begin{array}{l}2.64 * * * \\
(0.53)\end{array}$ & $\begin{array}{l}2.66^{* * *} \\
(0.53)\end{array}$ & $\begin{array}{l}2.64 * * * \\
(0.53)\end{array}$ & $\begin{array}{l}2.76 * * * \\
(0.55)\end{array}$ \\
\hline Pseudo R2 & 0.02 & 0.03 & 0.04 & 0.04 & 0.04 \\
\hline $\begin{array}{l}\text { (-) Log- } \\
\text { Likelihood }\end{array}$ & 27092 & 26783 & 26777 & 26752 & 26486 \\
\hline $\mathbf{N}$ & 43605 & 43605 & 43605 & 43605 & 43206 \\
\hline
\end{tabular}

Source:Authors' computations using 2008-2010-2012 Turkish Health Survey

Notes:

$(1)^{* * *}$ indicates $1 \%$ level of significance, $* *$ indicates $5 \%$ level of significance, *indicates $10 \%$ level of significance.

(2) Robust standard errors are shown in paranthesis.

(3) Marginal effects are computed at the means of the variables 
Table 4c. Marginal Effects from Probit Estimation Results for Exercise with Education Levels (\%)

\begin{tabular}{|c|c|c|c|c|c|}
\hline Variable & $(1)$ & $(2)$ & $(3)$ & $(4)$ & $(5)$ \\
\hline \multicolumn{6}{|c|}{ Education } \\
\hline Non-Graduate & $\begin{array}{l}10.21 * * * \\
(1.06)\end{array}$ & $\begin{array}{l}8.89 * * * \\
(1.06)\end{array}$ & $\begin{array}{l}8.78 * * * \\
(1.06)\end{array}$ & $\begin{array}{l}8.96 * * * \\
(1.06)\end{array}$ & $\begin{array}{l}8.80 * * * \\
(1.06)\end{array}$ \\
\hline $\begin{array}{l}\text { Primary } \\
\text { School }\end{array}$ & $\begin{array}{l}16.80 * * * \\
(0.68)\end{array}$ & $\begin{array}{l}11.77 * * * \\
(0.73)\end{array}$ & $\begin{array}{l}11.56 * * * \\
(0.74)\end{array}$ & $\begin{array}{l}11.64 * * * \\
(0.74)\end{array}$ & $\begin{array}{l}11.57 * * * \\
(0.75)\end{array}$ \\
\hline Middle School & $\begin{array}{l}20.26 * * * \\
(0.96)\end{array}$ & $\begin{array}{l}15.29 * * * \\
(1.03)\end{array}$ & $\begin{array}{l}15.19 * * * \\
(1.03)\end{array}$ & $\begin{array}{l}15.11 * * * \\
(1.03)\end{array}$ & $\begin{array}{l}14.94 * * * \\
(1.05)\end{array}$ \\
\hline High School & $\begin{array}{l}20.56 * * * \\
(0.83)\end{array}$ & $\begin{array}{l}15.59 * * * \\
(0.92)\end{array}$ & $\begin{array}{l}15.55 * * * \\
(0.93)\end{array}$ & $\begin{array}{l}15.26 * * * \\
(0.93)\end{array}$ & $\begin{array}{l}15.10 * * * \\
(0.97)\end{array}$ \\
\hline University+ & $\begin{array}{l}21.49 * * * \\
(0.88)\end{array}$ & $\begin{array}{l}16.82 * * * \\
(0.97)\end{array}$ & $\begin{array}{l}16.90 * * * \\
(0.98)\end{array}$ & $\begin{array}{l}15.82 * * * \\
(0.99)\end{array}$ & $\begin{array}{l}15.57 * * * \\
(1.08)\end{array}$ \\
\hline Male & $\begin{array}{l}4.58 * * * \\
(0.46)\end{array}$ & $\begin{array}{l}5.35 * * * \\
(0.46)\end{array}$ & $\begin{array}{l}5.21 * * * \\
(0.47)\end{array}$ & $\begin{array}{l}3.40 * * \\
(0.55)\end{array}$ & $\begin{array}{l}3.47 * * * \\
(0.55)\end{array}$ \\
\hline $\operatorname{Age}\left(\times 10^{-1}\right)$ & & $\begin{array}{l}15.88 * * * \\
(1.01)\end{array}$ & $\begin{array}{l}15.07 * * * \\
(1.04)\end{array}$ & $\begin{array}{l}14.83 * * * \\
(1.04)\end{array}$ & $\begin{array}{l}14.69 * * * \\
(1.05)\end{array}$ \\
\hline $\begin{array}{l}\text { Age } \\
\operatorname{Square}\left(\times 10^{-3}\right)\end{array}$ & & $\begin{array}{l}-17.84 * * * \\
(0.97)\end{array}$ & $\begin{array}{l}-17.03 * * * \\
(1.00)\end{array}$ & $\begin{array}{l}-16.38 * * * \\
(1.00)\end{array}$ & $\begin{array}{l}-16.26 * * * \\
(1.01)\end{array}$ \\
\hline Urban & & $\begin{array}{l}-4.41 * * * \\
(0.51)\end{array}$ & $\begin{array}{l}-4.38 * * * \\
(0.51)\end{array}$ & $\begin{array}{l}-3.92 * * * \\
(0.51)\end{array}$ & $\begin{array}{l}-3.81 * * * \\
(0.53)\end{array}$ \\
\hline \multicolumn{6}{|c|}{ Marital Status } \\
\hline Married & & & $\begin{array}{l}1.81 * * \\
(0.78)\end{array}$ & $\begin{array}{l}2.16 * * * \\
(0.78)\end{array}$ & $\begin{array}{l}1.97 * * \\
(0.78)\end{array}$ \\
\hline Single & & & $\begin{array}{l}-0.43 \\
(1.14)\end{array}$ & $\begin{array}{l}-0.01 \\
(1.15)\end{array}$ & $\begin{array}{l}-0.21 \\
(1.15)\end{array}$ \\
\hline \multicolumn{6}{|c|}{ Labor Force Status } \\
\hline Employed & & & & $\begin{array}{l}4.06 * * * \\
(0.58)\end{array}$ & $\begin{array}{l}4.11 * * * \\
(0.58)\end{array}$ \\
\hline Unemployed & & & & $\begin{array}{l}0.38 \\
(1.37)\end{array}$ & $\begin{array}{l}0.18 \\
(1.39)\end{array}$ \\
\hline $\begin{array}{l}\text { Log Household } \\
\text { Income }\end{array}$ & & & & & $\begin{array}{l}0.20 \\
(0.45)\end{array}$ \\
\hline Dummy10 & $\begin{array}{l}7.74 * * * \\
(0.62)\end{array}$ & $\begin{array}{l}8.20 * * * \\
(0.62)\end{array}$ & $\begin{array}{l}8.22 * * * \\
(0.62)\end{array}$ & $\begin{array}{l}8.19 * * * \\
(0.62)\end{array}$ & $\begin{array}{l}8.17 * * * \\
(0.62)\end{array}$ \\
\hline Dummy12 & $\begin{array}{l}2.13 * * * \\
(0.53)\end{array}$ & $\begin{array}{l}2.64 * * * \\
(0.53)\end{array}$ & $\begin{array}{l}2.66 * * * \\
(0.53)\end{array}$ & $\begin{array}{l}2.64 * * * \\
(0.53)\end{array}$ & $\begin{array}{l}2.76 * * * \\
(0.55)\end{array}$ \\
\hline Pseudo R2 & 0.02 & 0.04 & 0.04 & 0.04 & 0.04 \\
\hline $\begin{array}{l}\text { (-) Log- } \\
\text { Likelihood }\end{array}$ & 27076 & 26773 & 26767 & 26741 & 26476 \\
\hline $\mathbf{N}$ & 43605 & 43605 & 43605 & 43605 & 43206 \\
\hline
\end{tabular}

Source:Authors' computations using 2008-2010-2012 Turkish Health Survey

Notes:

$(1)^{* * *}$ indicates $1 \%$ level of significance, $* *$ indicates $5 \%$ level of significance, *indicates $10 \%$ level of significance.

(2) Robust standard errors are shown in paranthesis.

(3) Marginal effects are computed at the means of the variables 
Table 5a. Descriptive Statistics for BMI

\begin{tabular}{|c|c|c|c|c|c|}
\hline Variable & $\begin{array}{l}\text { Underweight } \\
(\mathrm{BMI}<18.5)\end{array}$ & $\begin{array}{l}\text { Normal Weight } \\
(18.5<=\text { BMI }<=24.99)\end{array}$ & $\begin{array}{l}\text { Overweight } \\
(25<=B M I<30)\end{array}$ & $\begin{array}{l}\text { Obese } \\
(\text { BMI }>=30)\end{array}$ & Total \\
\hline Male* & $\begin{array}{l}0.01 \\
(0.10)\end{array}$ & $\begin{array}{l}0.37 \\
(0.48)\end{array}$ & $\begin{array}{l}0.45 \\
(0.50)\end{array}$ & $\begin{array}{l}0.17 \\
(0.38)\end{array}$ & 1.00 \\
\hline Female* & $\begin{array}{l}0.02 \\
(0.15)\end{array}$ & $\begin{array}{l}0.38 \\
(0.48)\end{array}$ & $\begin{array}{l}0.34 \\
(0.47)\end{array}$ & $\begin{array}{l}0.26 \\
(0.44)\end{array}$ & 1.00 \\
\hline Age (Years) & $\begin{array}{l}42.57 \\
(16.79)\end{array}$ & $\begin{array}{l}43.77 \\
(14.96)\end{array}$ & $\begin{array}{l}47.47 \\
(13.94)\end{array}$ & $\begin{array}{l}50.51 \\
(13.08)\end{array}$ & $\begin{array}{l}46.65 \\
(14.44)\end{array}$ \\
\hline Age-Squared & $\begin{array}{l}2093 \\
(1759)\end{array}$ & $\begin{array}{l}2139 \\
(1534)\end{array}$ & $\begin{array}{l}2447 \\
(1443)\end{array}$ & $\begin{array}{l}2722 \\
(1385)\end{array}$ & $\begin{array}{l}2385 \\
(1489)\end{array}$ \\
\hline Urban* & $\begin{array}{l}0.02 \\
(0.13)\end{array}$ & $\begin{array}{l}0.37 \\
(0.48)\end{array}$ & $\begin{array}{l}0.39 \\
(0.49)\end{array}$ & $\begin{array}{l}0.22 \\
(0.41)\end{array}$ & 1.00 \\
\hline Rural* & $\begin{array}{l}0.02 \\
(0.14)\end{array}$ & $\begin{array}{l}0.37 \\
(0.48)\end{array}$ & $\begin{array}{l}0.39 \\
(0.48)\end{array}$ & $\begin{array}{l}0.22 \\
(0.41)\end{array}$ & 1.00 \\
\hline \multicolumn{6}{|c|}{ Marital Status } \\
\hline Married* & $\begin{array}{l}0.01 \\
(0.12)\end{array}$ & $\begin{array}{l}0.35 \\
(0.48)\end{array}$ & $\begin{array}{l}0.41 \\
(0.49)\end{array}$ & $\begin{array}{l}0.23 \\
(0.42)\end{array}$ & 1.00 \\
\hline Single* & $\begin{array}{l}0.05 \\
(0.23)\end{array}$ & $\begin{array}{l}0.62 \\
(0.49)\end{array}$ & $\begin{array}{l}0.25 \\
(0.44)\end{array}$ & $\begin{array}{l}0.08 \\
(0.26)\end{array}$ & 1.00 \\
\hline Widowed/Divorced* & $\begin{array}{l}0.02 \\
(0.14)\end{array}$ & $\begin{array}{l}0.35 \\
(0.48)\end{array}$ & $\begin{array}{l}0.35 \\
(0.48)\end{array}$ & $\begin{array}{l}0.28 \\
(0.45)\end{array}$ & 1.00 \\
\hline \multicolumn{6}{|c|}{ Education } \\
\hline Years of Schooling & $\begin{array}{l}7.73 \\
(4.82)\end{array}$ & $\begin{array}{l}7.56 \\
(4.54)\end{array}$ & $\begin{array}{l}6.99 \\
(4.30)\end{array}$ & $\begin{array}{l}5.81 \\
(4.02)\end{array}$ & $\begin{array}{l}6.96 \\
(4.39)\end{array}$ \\
\hline $\begin{array}{l}\text { Years of Schooling- } \\
\text { Squared }\end{array}$ & $\begin{array}{l}82.87 \\
(80.44)\end{array}$ & $\begin{array}{l}77.77 \\
(76.78)\end{array}$ & $\begin{array}{l}67.39 \\
(71.75)\end{array}$ & $\begin{array}{l}49.98 \\
(61.99)\end{array}$ & $\begin{array}{l}67.78 \\
(72.65)\end{array}$ \\
\hline Illiterate* & $\begin{array}{l}0.02 \\
(0.14)\end{array}$ & $\begin{array}{l}0.34 \\
(0.47)\end{array}$ & $\begin{array}{l}0.34 \\
(0.48)\end{array}$ & $\begin{array}{l}0.30 \\
(0.46)\end{array}$ & 1.00 \\
\hline Non-Graduate* & $\begin{array}{l}0.02 \\
(0.12)\end{array}$ & $\begin{array}{l}0.31 \\
(0.46)\end{array}$ & $\begin{array}{l}0.37 \\
(0.48)\end{array}$ & $\begin{array}{l}0.30 \\
(0.46)\end{array}$ & 1.00 \\
\hline Primary School* & $\begin{array}{l}0.01 \\
(0.11)\end{array}$ & $\begin{array}{l}0.34 \\
(0.47)\end{array}$ & $\begin{array}{l}0.40 \\
(0.49\end{array}$ & $\begin{array}{l}0.25 \\
(0.43)\end{array}$ & 1.00 \\
\hline Middle School* & $\begin{array}{l}0.02 \\
(0.14)\end{array}$ & $\begin{array}{l}0.40 \\
(0.49)\end{array}$ & $\begin{array}{l}0.40 \\
(0.49)\end{array}$ & $\begin{array}{l}0.18 \\
(0.38)\end{array}$ & 1.00 \\
\hline High School* & $\begin{array}{l}0.02 \\
(0.14)\end{array}$ & $\begin{array}{l}0.44 \\
(0.50)\end{array}$ & $\begin{array}{l}0.39 \\
(0.49)\end{array}$ & $\begin{array}{l}0.15 \\
(0.36)\end{array}$ & 1.00 \\
\hline University+* & $\begin{array}{l}0.02 \\
(0.16)\end{array}$ & $\begin{array}{l}0.47 \\
(0.50)\end{array}$ & $\begin{array}{l}0.38 \\
(0.49)\end{array}$ & $\begin{array}{l}0.13 \\
(0.33)\end{array}$ & 1.00 \\
\hline \multicolumn{6}{|c|}{ Labor Market Status } \\
\hline Employed* & $\begin{array}{l}0.02 \\
(0.13)\end{array}$ & $\begin{array}{l}0.41 \\
(0.49)\end{array}$ & $\begin{array}{l}0.41 \\
(0.49)\end{array}$ & $\begin{array}{l}0.16 \\
(0.37)\end{array}$ & 1.00 \\
\hline Unemployed* & $\begin{array}{l}0.03 \\
(0.17)\end{array}$ & $\begin{array}{l}0.53 \\
(0.50)\end{array}$ & $\begin{array}{l}0.35 \\
(0.48)\end{array}$ & $\begin{array}{l}0.09 \\
(0.28)\end{array}$ & 1.00 \\
\hline Out of Labor Force* & $\begin{array}{l}0.02 \\
(0.14)\end{array}$ & $\begin{array}{l}0.34 \\
(0.47)\end{array}$ & $\begin{array}{l}0.38 \\
(0.48)\end{array}$ & $\begin{array}{l}0.26 \\
(0.44)\end{array}$ & 1.00 \\
\hline $\begin{array}{l}\text { Log Household Income } \\
\text { (TL) }\end{array}$ & $\begin{array}{l}6.88 \\
(0.64)\end{array}$ & $\begin{array}{l}6.95 \\
(0.63)\end{array}$ & $\begin{array}{l}6.98 \\
(0.59)\end{array}$ & $\begin{array}{l}6.95 \\
(0.59)\end{array}$ & $\begin{array}{l}6.96 \\
(0.61)\end{array}$ \\
\hline $\begin{array}{l}\text { Number of Observations } \\
\text { in } 2008\end{array}$ & 209 & 3998 & 3764 & 1943 & 9914 \\
\hline $\begin{array}{l}\text { Number of Observations } \\
\text { in } 2010\end{array}$ & 201 & 3844 & 3928 & 2317 & 10290 \\
\hline $\begin{array}{l}\text { Number of Observations } \\
\text { in } 2012\end{array}$ & 322 & 7570 & 8331 & 4647 & 20870 \\
\hline Total Observations & 732 & 15412 & 16023 & 8907 & 41074 \\
\hline
\end{tabular}

Source: 2008,2010,2012 Turkish Health Survey

Notes : (1)*indicates a dummy variable

(2) The numbers in the paranthesis are standard deviations 
Table 5b. OLS Estimation Results for BMI with Years of Schooling

\begin{tabular}{|c|c|c|c|c|c|}
\hline Variable & $(1)$ & (2) & (3) & (4) & $(5)$ \\
\hline $\begin{array}{l}\text { Years of } \\
\text { Schooling }\end{array}$ & $\begin{array}{l}-0.13 * * * \\
(0.02)\end{array}$ & $\begin{array}{l}-0.07 * * * \\
(0.02)\end{array}$ & $\begin{array}{l}-0.08 * * * \\
(0.02)\end{array}$ & $\begin{array}{l}-0.09 * * * \\
(0.02)\end{array}$ & $\begin{array}{l}-0.11 * * * \\
(0.02)\end{array}$ \\
\hline $\begin{array}{l}\text { Years of } \\
\text { Schooling } \\
\text { Square }\end{array}$ & $\begin{array}{l}-0.003 * * \\
(0.001)\end{array}$ & $\begin{array}{l}-0.003 * * * \\
(0.001)\end{array}$ & $\begin{array}{l}-0.001 * * * \\
(0.001)\end{array}$ & $\begin{array}{l}-0.001 * * * \\
(0.001)\end{array}$ & $\begin{array}{l}-0.001 * * * \\
(0.001)\end{array}$ \\
\hline Male & $\begin{array}{l}-0.22 * * * \\
(0.04)\end{array}$ & $\begin{array}{l}-0.41 * * * \\
(0.04)\end{array}$ & $\begin{array}{l}-0.36 * * * \\
(0.04)\end{array}$ & $\begin{array}{l}-0.13 * * * \\
(0.05)\end{array}$ & $\begin{array}{l}-0.08 * * * \\
(0.05)\end{array}$ \\
\hline $\operatorname{Age}\left(\mathrm{x10}^{-1}\right)$ & & $\begin{array}{l}5.11 * * * \\
(0.10)\end{array}$ & $\begin{array}{l}4.73 * * * \\
(0.10)\end{array}$ & $\begin{array}{l}4.76 * * * \\
(0.10)\end{array}$ & $\begin{array}{l}4.64 * * * \\
(0.10)\end{array}$ \\
\hline $\begin{array}{l}\text { Age } \\
\text { Square }\left(\times 10^{-3}\right)\end{array}$ & & $\begin{array}{l}-4.50 * * * \\
(0.10)\end{array}$ & $\begin{array}{l}-4.20 * * * \\
(0.10)\end{array}$ & $\begin{array}{l}-4.28 * * * \\
(0.10)\end{array}$ & $\begin{array}{l}-4.19 * * * \\
(0.10)\end{array}$ \\
\hline Urban & & $\begin{array}{l}0.46^{* * *} \\
(0.05)\end{array}$ & $\begin{array}{l}0.44 * * * \\
(0.05)\end{array}$ & $\begin{array}{l}0.40 * * * \\
(0.05)\end{array}$ & $\begin{array}{l}0.30 * * * \\
(0.05)\end{array}$ \\
\hline \multicolumn{6}{|c|}{ Marital Status } \\
\hline Married & & & $\begin{array}{l}-0.12 \\
(0.09)\end{array}$ & $\begin{array}{l}-0.19 * * \\
(0.09)\end{array}$ & $\begin{array}{l}-0.25 * * * \\
(0.09)\end{array}$ \\
\hline Single & & & $\begin{array}{l}-1.55^{* * *} \\
(0.12)\end{array}$ & $\begin{array}{l}-1.52 * * * \\
(0.12)\end{array}$ & $\begin{array}{l}-1.60 * * * \\
(0.12)\end{array}$ \\
\hline \multicolumn{6}{|c|}{ Labor Force Status } \\
\hline Employed & & & & $\begin{array}{l}-0.41 * * * \\
(0.05)\end{array}$ & $\begin{array}{l}-0.44 * * * \\
(0.05)\end{array}$ \\
\hline Unemployed & & & & $\begin{array}{l}-1.12 * * * \\
(0.11)\end{array}$ & $\begin{array}{l}-0.96^{* * * *} \\
(0.11)\end{array}$ \\
\hline $\begin{array}{l}\text { Log } \\
\text { Household } \\
\text { Income }\end{array}$ & & & & & $\begin{array}{l}0.43 * * * \\
(0.04)\end{array}$ \\
\hline Dummy10 & $\begin{array}{l}0.41 * * * \\
(0.06)\end{array}$ & $\begin{array}{l}0.31 * * * \\
(0.06)\end{array}$ & $\begin{array}{l}0.32 * * * \\
(0.06)\end{array}$ & $\begin{array}{l}0.32 * * * \\
(0.06)\end{array}$ & $\begin{array}{l}0.27 * * * \\
(0.06)\end{array}$ \\
\hline Dummy12 & $\begin{array}{l}0.57 * * * \\
(0.05)\end{array}$ & $\begin{array}{l}0.44 * * * \\
(0.05)\end{array}$ & $\begin{array}{l}0.44 * * * \\
(0.05)\end{array}$ & $\begin{array}{l}0.44 * * * \\
(0.05)\end{array}$ & $\begin{array}{l}0.29 * * * \\
(0.05)\end{array}$ \\
\hline $\mathbf{R 2}$ & 0.03 & 0.10 & 0.10 & 0.10 & 0.11 \\
\hline Adjusted R2 & 0.03 & 0.10 & 0.10 & 0.10 & 0.11 \\
\hline $\mathbf{N}$ & 41074 & 41074 & 41074 & 41074 & 40699 \\
\hline
\end{tabular}

Source:Authors' computations using 2008, 2010 and 2012 Turkish Health Survey

Notes:

(1)*** indicates $1 \%$ level of significance, $* *$ indicates $5 \%$ level of significance, *indicates $10 \%$ level of significance.

(2) Robust standard errors are shown in paranthesis. 
Table 5c. OLS Estimation Results for BMI with Education Levels

\begin{tabular}{|c|c|c|c|c|c|}
\hline Variable & $(1)$ & $(2)$ & (3) & $(4)$ & $(5)$ \\
\hline \multicolumn{6}{|c|}{ Education } \\
\hline Non- & 0.20 & $0.24 *$ & $0.25^{*}$ & $0.23 *$ & 0.21 \\
\hline Graduate & $(0.14)$ & $(0.13)$ & $(0.13)$ & $(0.13)$ & $(0.13)$ \\
\hline Primary & $-0.33 * * *$ & $-0.22 * *$ & $-0.25 * * *$ & $-0.26 * * *$ & $-0.38 * * *$ \\
\hline School & $(0.09)$ & $(0.09)$ & $(0.09)$ & $(0.09)$ & $(0.09)$ \\
\hline Middle & $-1.19 * * *$ & $-0.69 * * *$ & $-0.67 * * *$ & $-0.67 * * *$ & $-0.87 * * *$ \\
\hline School & $(0.11)$ & $(0.11)$ & $(0.11)$ & $(0.11)$ & $(0.11)$ \\
\hline High School & $\begin{array}{l}-1.76^{* * * *} \\
(0.10)\end{array}$ & $\begin{array}{l}-1.15 * * * \\
(0.10)\end{array}$ & $\begin{array}{l}-1.09 * * * \\
(0.10)\end{array}$ & $\begin{array}{l}-1.08 * * * \\
(0.10)\end{array}$ & $\begin{array}{l}-1.35 * * * \\
(0.11)\end{array}$ \\
\hline University+ & $\begin{array}{l}-2.12^{* * * *} \\
(0.10)\end{array}$ & $\begin{array}{l}-1.55^{* * *} \\
(0.10)\end{array}$ & $\begin{array}{l}-1.40 * * * \\
(0.10)\end{array}$ & $\begin{array}{l}-1.32 * * * \\
(0.10)\end{array}$ & $\begin{array}{l}-1.72 * * * \\
(0.11)\end{array}$ \\
\hline Male & $\begin{array}{l}-0.24 * * * \\
(0.04)\end{array}$ & $\begin{array}{l}-0.42 * * * \\
(0.04)\end{array}$ & $\begin{array}{l}-0.37 * * * \\
(0.04)\end{array}$ & $\begin{array}{l}-0.14 * * * \\
(0.05)\end{array}$ & $\begin{array}{l}-0.09 \\
(0.05)\end{array}$ \\
\hline $\operatorname{Age}\left(\mathrm{x10}^{-1}\right)$ & & $\begin{array}{l}5.07 * * * \\
(0.10)\end{array}$ & $\begin{array}{l}4.71 * * * \\
(0.10)\end{array}$ & $\begin{array}{l}4.73 * * * \\
(0.10)\end{array}$ & $\begin{array}{l}4.61 * * * \\
(0.11)\end{array}$ \\
\hline $\begin{array}{l}\text { Age } \\
\text { Square }\left(\mathbf{x 1 0}^{-3}\right)\end{array}$ & & $\begin{array}{l}-4.46 * * * \\
(0.10)\end{array}$ & $\begin{array}{l}-4.18 * * * \\
(0.10)\end{array}$ & $\begin{array}{l}-4.26 * * * \\
(0.10)\end{array}$ & $\begin{array}{l}-4.16^{* * * *} \\
(0.10)\end{array}$ \\
\hline Urban & & $\begin{array}{l}0.46^{* * * *} \\
(0.05)\end{array}$ & $\begin{array}{l}0.45^{* * * *} \\
(0.05)\end{array}$ & $\begin{array}{l}0.41 * * * \\
(0.05)\end{array}$ & $\begin{array}{l}0.30 * * * \\
(0.05)\end{array}$ \\
\hline \multicolumn{6}{|c|}{ Marital Status } \\
\hline Married & & & $\begin{array}{l}-0.14 \\
(0.09)\end{array}$ & $\begin{array}{l}-0.21 * * \\
(0.09)\end{array}$ & $\begin{array}{l}-0.27 * * \\
(0.09)\end{array}$ \\
\hline Single & & & $\begin{array}{l}-1.56^{* * * *} \\
(0.12)\end{array}$ & $\begin{array}{l}-1.54 * * * \\
(0.12)\end{array}$ & $\begin{array}{l}-1.62 * * * \\
(0.12)\end{array}$ \\
\hline \multicolumn{6}{|c|}{ Labor Force Status } \\
\hline Employed & & & & $\begin{array}{l}-0.41 * * * \\
(0.05)\end{array}$ & $\begin{array}{l}-0.45 * * * \\
(0.05)\end{array}$ \\
\hline Unemployed & & & & $\begin{array}{l}-1.12 * * * \\
(0.11)\end{array}$ & $\begin{array}{l}-0.96^{* * * *} \\
(0.11)\end{array}$ \\
\hline $\begin{array}{l}\text { Log } \\
\text { Household } \\
\text { Income }\end{array}$ & & & & & $\begin{array}{l}0.43 * * * \\
(0.04)\end{array}$ \\
\hline Dummy10 & $\begin{array}{l}0.42 * * * \\
(0.06)\end{array}$ & $\begin{array}{l}0.31 * * * \\
(0.06)\end{array}$ & $\begin{array}{l}0.32 * * * \\
(0.06)\end{array}$ & $\begin{array}{l}0.32 * * * \\
(0.06)\end{array}$ & $\begin{array}{l}0.26 * * * \\
(0.06)\end{array}$ \\
\hline Dummy12 & $\begin{array}{l}0.58 * * * \\
(0.05)\end{array}$ & $\begin{array}{l}0.44 * * * \\
(0.05)\end{array}$ & $\begin{array}{l}0.44 * * * \\
(0.05)\end{array}$ & $\begin{array}{l}0.44 * * * \\
(0.05)\end{array}$ & $\begin{array}{l}0.29 * * * \\
(0.05)\end{array}$ \\
\hline $\mathbf{R 2}$ & 0.03 & 0.10 & 0.10 & 0.10 & 0.11 \\
\hline Adjusted R2 & 0.03 & 0.10 & 0.10 & 0.10 & 0.10 \\
\hline $\mathbf{N}$ & 41074 & 41074 & 41074 & 41074 & 40699 \\
\hline
\end{tabular}

Source:Authors' computations using 2008-2010-2012 Turkish Health Survey

Notes:

(1)*** indicates $1 \%$ level of significance, $* *$ indicates $5 \%$ level of significance, *indicates $10 \%$ level of significance.

(2) Robust standard errors are shown in paranthesis. 
Figure 1. Marginal Effects (x100) (For BMI, the OLS Coefficients) by Education Level
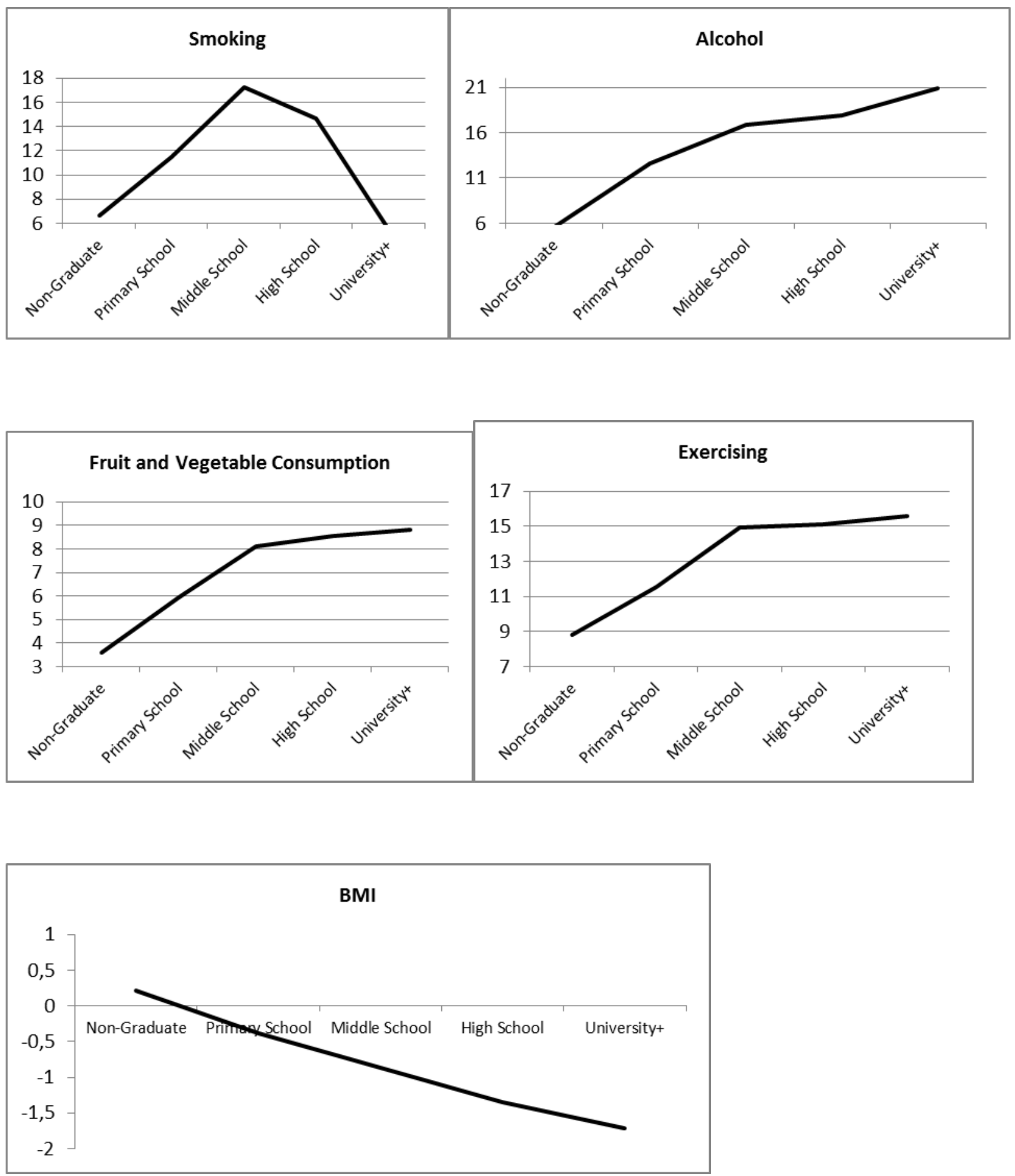